\title{
The roles of KIBS and R\&D in the industrial diversification of regions
}

\author{
Jeroen Content ${ }^{1}$ (D) $\cdot$ Nicola Cortinovis ${ }^{2} \cdot$ Koen Frenken $^{3} \cdot$ Jacob Jordaan $^{1}$
}

Received: 18 October 2019 / Accepted: 11 June 2021 / Published online: 27 June 2021

(c) The Author(s) 2021

\begin{abstract}
There is a growing recognition of the importance of the creation of new industrial specialisations for sustained regional growth. However, path dependency often limits a region's ability to do so, as the occurrence of new industrial specialisations is conditioned by its existing industrial base. In this paper, we use data for 269 NUTS-2 EU regions to examine whether regional Knowledge-Intensive Business Services (KIBS) and Research and Development (R\&D) enhance the capacity of regions to specialise in new industries, against the forces of path dependence. Our findings show that both KIBS and R\&D exercise direct positive effects on the creation of new industry specialisations and that professional-KIBS and public R\&D impact negatively on the relatedness of new specialisations, while private R\&D does so positively.
\end{abstract}

JEL Classification R11 · O32 · L84

Jeroen Content

j.content@uu.nl

Nicola Cortinovis

cortinovis@ese.eur.nl

Koen Frenken

k.frenken@uu.nl

Jacob Jordaan

j.a.jordaan@uu.nl

1 Utrecht University School of Economics, Utrecht, The Netherlands

2 Erasmus School of Economics, Erasmus University Rotterdam, Rotterdam, The Netherlands

3 Copernicus Institute of Sustainable Development, Utrecht University, Utrecht, The Netherlands 


\section{Introduction}

Following the seminal article by Hidalgo et al. (2007), there has been an incredible interest in the analysis of processes underlying the rise of new specialisations of economies. A persistent finding in this literature is that the process of industrial diversification in countries and regions is contingent on pre-existing activities in related industries (Boschma 2017; Content and Frenken 2016). Accordingly, new industrial specialisations in economies emerge as a branching process in which new economic activities branch-out of established activities (Boschma and Frenken 2011; Frenken and Boschma 2007). Underlying this notion of industrial branching is the idea that once an economy has developed the capabilities and knowledge to specialise in a particular industry, it becomes easier to diversify into cognitively related industries. Economic growth can therefore sometimes lead to a path-dependent development in which the degree of relatedness among a regions' economic activities limits its future diversification patterns (Isaksen 2015; Martin and Sunley 2006).

As technological changes and shifts in global demand can over time make regional industrial specialisations obsolete, it is crucial to understand how regional economies can diversify into unrelated activities and structurally renew their industrial specialisations. This gives rise to the question whether there are certain conditions that affect an economy's capability to diversify and escape the forces of path dependence. So far, studies that have addressed this question have examined whether factors such as innovative capacity, liberal market institutions, bridging social capital, high-income levels, extra-regional linkages, and entrepreneurship allow regions to break with path dependence by enabling them to diversify into less related activities (Boschma and Capone 2015; Cortinovis et al. 2017; Neffke et al. 2018; Petralia et al. 2017; Xiao et al. 2018; Zhu et al. 2017). However, more knowledge is still needed to develop our understanding of the nature and effects of conditions that underlie unrelated diversification.

In this study, we propose that Knowledge-Intensive Business Services (KIBS) and Research \& Development (R\&D) provide regions with the conditions to diversify into more unrelated activities. These conditions come in the form of access to extra-regional knowledge linkages and by enabling regional actors to bridge and recombine knowledge from otherwise unrelated industries. KIBS are often argued to play an important role in systems of innovation (Czarnitzki and Spielkamp 2003), yet are overlooked when it comes to their potential role in (unrelated) industrial diversification. Innovative capacity and R\&D are analysed and found to play a role in this respect (Xiao et al. 2018; Zhu et al. 2017); however, exactly what type of R\&D is important has remained implicit. We study together R\&D and KIBS because of their distinct but connected roles in systems of innovation. Where R\&D can be seen as the primary creator of new knowledge, KIBS are more important in the appropriation of available knowledge by others and in other parts of the economy. KIBS form a true source of new capabilities for firms, while R\&D is less important in that respect.

In our empirical analysis, we relate KIBS and R\&D to the occurrence-as well as the relatedness - of new industrial specialisations for the period of 2006-2013 
for 269 NUTS-2 regions across Europe. We split up the effect of R\&D expenditure into a private and public component, since their aims and potential effects on innovation are different (Aghion et al. 2008). Researchers within an academic setting are able to pursue more freely their own interests, which can result in more fundamental research and knowledge. Private R\&D is driven more by commercial interest as to secure a market position for the firm, which results in applied research and knowledge. We also split-up the presence of KIBS into different components, professional-KIBS and technical-KIBS, as the types of knowledge and how they are exchanged with their clients are different between the two (Landry et al. 2012).

Our results indicate that KIBS and R\&D in general support the emergence of new industrial specialisations as well as moderate the effects of relatedness, suggesting that KIBS and R\&D compensate for a lack of local related knowledge and capabilities. Methodologically, we make a contribution by analysing the effects on the the relatedness of new industrial specialisations in a more direct way. We find that especially professional-KIBS are associated with a lower relatedness of new specialisations. Interestingly, the effect of $R \& D$ in this sense is more ambiguous, as we find that R\&D stemming from the private sector increases the relatedness of new specialisations, whereas R\&D stemming from the public sector strongly decreases the relatedness of new specialisations.

In the remainder of this paper, we review the literature relevant for this study in Sect. 2, present the data and methodology in Sect. 3, and discuss the results in Sect. 4. Finally, Sect. 5 concludes with some final remarks and policy implications.

\section{Literature review}

\subsection{Inter-industry relatedness and industrial diversification of regions}

Industries can be described as collections of firms that operate on common markets and share technologies, capabilities, and knowledge. The process of industrial diversification in which new industries arise or old industries exit an economy is brought about by the entry and/or exit of firms in those industries. Accordingly, this also means the entry and exit of technologies, capabilities, and knowledge. These technologies, capabilities, and knowledge that the entering and exiting firms take in or out of an industry and the economy can be more or less related to those possessed by incumbent firms. The presence of firms operating in a particular industry can in this way also impact the likelihood of entry and growth of other firms, as firms operating in related industries can draw on already present capabilities and knowledge. The barriers for entry are lower for related firms and the effort required to survive or enter for unrelated firms is increased; on aggregate, this results in a specific kind of industrial diversification in which economies branch out their industry portfolio into related activities (Frenken and Boschma 2007).

Empirically this theory is assessed by Hidalgo et al. (2007), who find that at the country-level economies tend to become specialised in products that are related to products that they already export. Measuring co-production of products in Swedish 
plants, Neffke et al. (2011) show that also at the regional level economies are subject to this pattern of related diversification. Further corroborating evidence is found by Boschma et al. (2013) for Spanish regions and Essletzbichler (2015) for metropolitan areas in the USA, ${ }^{1}$ showing that the relatedness of knowledge and capabilities required by firms and industries has a highly significant impact on the direction of diversification, i.e. related or unrelated. Drawing on the above-mentioned findings, we formulate our first hypothesis as follows:

Hypothesis 1 The probability of a new industry entering a region is positively associated with its degree of relatedness with the existing industry base.

While less common and also left unexplained by the former findings, economies do occasionally diversify into unrelated industries (Coniglio et al. 2018). This raises the questions of whether certain economies are better capable of diversifying into unrelated industries and what underlying factors could influence this capability. At least one prerequisite for diversification into unrelated industries and to lower the barriers for entry of unrelated firms is the need for knowledge and capabilities that are different than the existing ones. A growing literature finds that factors such as formal and informal institutions, innovative capacity, and extra-regional linkages are important in facilitating this (Boschma and Capone 2015; Cortinovis et al. 2017; Neffke et al. 2018; Petralia et al. 2017; Xiao et al. 2018; Zhu et al. 2017). However, more evidence is needed to better understand how these factors facilitate the development or acquisition of new (unrelated) knowledge and capabilities and what other factors may be important. For instance, while innovation capacity is found to play a role, exactly which innovation capacity matters remains uncertain.

Here, we investigate two factors that may decrease a region's dependence on related industrial diversification for economic development: the presence of Knowledge-Intensive Business Services (KIBS) and Research \& Development (R\&D). These factors may provide generic competences of running businesses and innovation capacity, which can be used in many different-and unrelated-industry contexts. KIBS are viewed to fulfil an important function in systems of innovation (Muller and Zenker 2001), yet are overlooked when it comes to their potential role in (unrelated) industrial diversification. Innovation capacity as proxied by $\mathrm{R} \& \mathrm{D}$ expenditures is analysed and found to be significant in this respect (Xiao et al. 2018); however, exactly what type of R\&D matters for what type of diversification has remained implicit. We study together the effects of R\&D and KIBS for industrial diversification of regional economies because of their distinct but connected roles in innovation networks. Where R\&D can be mainly seen as the generator of new knowledge, KIBS are more important in the appropriation and diffusion of available knowledge by and to others.

\footnotetext{
${ }^{1}$ For comprehensive reviews of this literature, see Content and Frenken (2016) and Boschma (2017).
} 


\subsection{Generation of new knowledge from research and development}

$\mathrm{R} \& \mathrm{D}$ in general is found to have a beneficial effect on the productivity and innovative activity of firms and on aggregate on industries and economies as well (Griliches 1991; Jaffe et al. 1993). Due to the non-rival nature of knowledge, the knowledge and ideas developed in one particular firm or research institute are able to spill over for third-parties to exploit. Yet in spite of the non-rival nature of knowledge, the fragmentation of trade networks, and advancements made in information and communication technologies, R\&D activities, and their spillovers remain characterised by a high degree of localisation (Audretsch and Feldman 1996; Bottazzi and Peri 2003; Feldman and Florida 1994; Simmie 2003). As a consequence, local learning, search routines, and utilisation of resources can sometimes contribute to path dependent diversification processes (Ahuja and Katila 2004; Maskell and Malmberg 2007; Neffke et al. 2011).

While spillovers from R\&D underlie localised learning and industrial specialisation, R\&D activities can also be a source of novelty as it can help a firm to absorb new knowledge developed by others. Local R\&D activities often build on global knowledge bases (Asheim and Isaksen 2002; Binz et al. 2016), combining local knowledge with new knowledge developed by others. In a more interactive way, collaborative R\&D linkages with distant firms-sometimes referred to as 'global pipelines' (Maskell et al. 2006) — form a source for the inflow of new and complementary insights. This can change the interpretation and perceived potentialities of local knowledge (Bathelt et al. 2004), which possibly leads to new and original recombinations of local and non-local knowledge. Finally, this can then initiate new diversification paths due to the development of new activities within an economy (Grillitsch and Trippl 2014; Tanner 2014; Trippl et al. 2017).

What is more, contrary to learning-by-doing, R\&D builds on generic knowledge and scientific principles which may apply to a wide set of products that otherwise may hardly be related (i.e. in terms of production). Hence, R\&D may facilitate the recombination of knowledge from cognitively distant industries. The boundary of firms' knowledge is often wider than the boundary of its production, making them better able to act upon innovation. R\&D-intensive firms can therefore be said to 'know more than they do' (Brusoni et al. 2001).

Considering this reasoning, the following two hypotheses are formulated:

Hypothesis $2 R \& D$ is positively associated with the probability of a region developing new industrial specialisations.

Hypothesis $3 R \& D$ negatively moderates the effect of relatedness on the probability that a region develops new industry specialisations.

Not all R\&D effort, however, is the same. One important distinguishing factor is whether R\&D activities are carried out in a private or public institutional setting. Where private $R \& D$ is mostly carried out by knowledge-intensive or hightech manufacturing firms, publicly funded R\&D activities are mostly carried out 
at universities or research institutes. This difference is important because private $\mathrm{R} \& \mathrm{D}$ is primarily performed to secure future profits or to increase the competitiveness of a business, confining the researcher to more applied research in areas that support such outcomes. Public R\&D is less dependent on securing a commercial outcome, thus granting more cognitive freedom to researchers and resulting in more fundamental types of research (Aghion et al. 2008). What is more, academic researchers are often in a more beneficial position within knowledge networks and are therefore able to obtain and get inspired by novel and unorthodox ideas (Forti et al. 2013; Lissoni 2010), giving them an advantage in combining knowledge across different and unrelated knowledge domains.

At the regional level, academic research and universities also form an important source of R\&D spillovers, and while the effect of this has been shown on local entrepreneurial activity and economic development (Acs et al. 1994), the effect on industrial diversification is not as prominent the literature. Accordingly, we formulate the following hypothesis:

Hypothesis 4 Public $R \& D$ is more important for the rise of unrelated industrial specialisations than private $R \& D$.

\subsection{Knowledge-intensive business services are central nodes in innovation networks}

KIBS are usually offered by private firms and are intermediate services that, due to the high levels of adaptability and customisation, require providers of these services to collaborate and interact closely with their customers (Den Hertog 2000). KIBS are regarded to have an important function in systems of innovation as mediators of knowledge flows (Muller and Zenker 2001). Knowledge generated by for instance R\&D investments spills over to others parts of the economy in multiple ways. KIBS can facilitate this process by acting as a joint partner to all kinds of different and institutionally diverse organisations, such as research institutes, multinational enterprises, or governments.

In the last decades, the use of KIBS is allowing firms to remain competitive in a more efficient way, given that globalisation and technological complexity have made it increasingly risky and expensive for firms to generate new knowledge in-house (Hipp 1999; Muller and Zenker 2001; Wood 2006). The provision of KIBS occurs as an interactive learning process, in which knowledge of client firms is combined with the knowledge of KIBS providers (Den Hertog 2002; Miles et al. 1995; Tomlinson 1999). As KIBS providers gather knowledge both from their clientele and from other sources (e.g. R\&D organisations, or universities), they play an important bridging role in knowledge and innovation networks and are sometimes referred to as brokers of knowledge (Czarnitzki and Spielkamp 2003; Toivonen 2004). Within these networks, KIBS are important in the creation, recombination, and diffusion of knowledge. 
Some empirical studies identify positive effects of KIBS on innovation in other firms and industries (Aslesen and Isaksen 2007; Rodriguez 2013), national gross output and productivity (Muller and Zenker 2001), and regional growth in longterm employment (Brenner et al. 2017). Others find that at the regional level a mutual and positive relationship exists between KIBS and manufacturing business (Lafuente et al. 2017; Wyrwich 2019). Moreover, KIBS are found to increase a client's absorptive capacity, specifically by increasing their capability to acquire new knowledge (Lau and Lo 2015).

As KIBS providers themselves also get inspired by knowledge from their clients, some of this knowledge spills over across different firms that make use of the same KIBS providers (Czarnitzki and Spielkamp 2003; Wood 2006). In consequence, KIBS firms not only function as a node or bridge between different types of actors within innovation networks, but can also function as a bridging platform for their clients and facilitate knowledge spillovers between them, fostering innovation in other parts of the economy (Janssen et al. 2018).

KIBS firms supply to a variety of clients in many different-and unrelatedindustry contexts, potentially enabling knowledge spillovers between unrelated firms and industries. Considering also that KIBS form a significant source of knowledge and capabilities for many firms, on aggregate the presence of KIBS might render the requirement to have related industries for the development of new economic activity less important. This leads us to formulate the following two hypotheses:

Hypothesis 5 The presence of KIBS is positively associated with the probability that a region develops new industrial specialisations.

Hypothesis 6 The presence of KIBS negatively moderates the effect of relatedness on the probability that a region develops new industry specialisations.

While KIBS firms form a distinct group of firms, within the group of KIBS firms marked differences are shown to exist between different types of KIBS firms. One common way of examining within group differences of KIBS firms is to make a distinction between professional services (P-KIBS) and technological services (T-KIBS) (Miles et al. 1995). The first type includes more traditional services (e.g. accounting, legal services, management consultancy, marketing, or design), whereas the second type includes services linked to technology (e.g. software development, technical engineering, information and communication technologies, or scientific research).

The main product that both these types of KIBS firms offer is knowledge, but the way this knowledge is sourced and in what form (i.e. codified or tacit) it is provided is proved to be different. Rodriguez et al. (2017) investigate how variety in external knowledge sourcing of KIBS firms in Spain is associated with innovation novelty. Regarding KIBS firms' sources of knowledge, they find that T-KIBS rely more on internal sources, scientific journals, technical publications, clients, and competitors, while P-KIBS rely more on suppliers. Landry et al. (2012) 
investigate what knowledge exchange strategies KIBS firms use with their clients and find that a mixture of tacit and codified knowledge exchange is practised most commonly. However, the propensity to use a commoditisation (codified knowledge) strategy over a personalisation strategy (tacit knowledge) rises with firms being classified as T-KIBS. With regard to the way knowledge is sourced and developed by KIBS firms themselves, differences are shown to exist in their cooperation behaviour with other organisations. Specifically, T-KIBS show a lower probability to cooperate with universities in their R\&D efforts as compared to P-KIBS (Fernandes and Ferreira 2013).

KIBS increase the exchange of disconnected pools of knowledge; in particular, KIBS mediate between their client's tacit knowledge base and the more publicly available codified knowledge in other parts of the economy (Windrum and Tomlinson 1999). While on aggregate this may be correct for all KIBS, taking into account T-KIBS' tendency to rely more on internal knowledge sources and their lower propensity to cooperate with universities it may well be that this is especially true for P-KIBS. This leads to formulate the following hypothesis:

Hypothesis 7 Professional-KIBS are more important for the rise of unrelated industrial specialisations than technological-KIBS.

\section{Data and methodology}

We construct a new dataset that combines the Orbis dataset provided by Bureau van Dijk with data provided by Eurostat for regions across Europe. The resulting dataset covers 269 NUTS-2 regions for 28 countries across Europe ${ }^{2}$ over the period 2006-2013. The Orbis dataset contains annual information on firm level employment and a NACE industry identifier at the 4-digit level. Using this information, we can aggregate employment at the 4-digit industry level to our spatial unit of analysis (NUTS-2). At the 4-digit level, the NACE classification distinguishes between about 600 different industries; however, as we exclude all non-tradable activities, the final dataset contains 283 different 4-digit industries.

\subsection{Industry specialisation and relatedness density}

A common approach to estimate relatedness of products is to use a proximity index capturing the co-occurrence of pairs of products that an economy trades with a competitive advantage (Hidalgo et al. 2007). The underlying assumption here is that a higher co-occurrence of a pair of products implies that apparently this pair requires similar capabilities and therefore would be related. Following the same reasoning, others have calculated inter-industry relatedness at the regional level with employment data by calculating whether a particular regions is relatively specialised in a

\footnotetext{
2 This includes 27 EU countries (excluding Malta) and Norway.
} 
particular industry using location quotients (Boschma et al. 2013; Cortinovis et al. 2017; Essletzbichler 2015; Neffke et al. 2011). In this study, we also adopt this approach by calculating relative specialisations with employment shares derived from the Orbis database.

We first determine whether a region is relatively specialised (based on the location quotient) in a particular industry by determining cut-off points for each industry using a bootstrapping procedure. Once we know in which industries regions are specialised, we calculate inter-industry relatedness based on the co-occurrences of industrial specialisations. The underlying assumption here is that with a rising probability of co-occurrence, so rise the shared knowledge and capabilities of a pair of industries. Following Hausmann and Klinger (2007), we also calculate industry density, which gives us an indication of in how many related industries a region is specialised relative to a particular reference industry. For a more elaborate discussion of this methodology, see Sect. 1 of the appendix.

\subsection{KIBS and R\&D}

We define our KIBS variable as the regional employment share of 2- and 3-digit industries that are referred to by Schnabl and Zenker (2013) as KIBS industries. ${ }^{3}$ Using this approach, we are also able to distinguish between professional-KIBS (P-KIBS) and technical-KIBS (T-KIBS). P-KIBS includes traditional professional services such as business \& management, legal accounting, or market research. T-KIBS includes mainly information and communication services such a software development but also engineering and architectural practices or testing and analytical activities, for instance.

From Eurostat, we derive annual data on R\&D expenditures in NUTS-2 regions. We divide this by the Gross Regional Product (GRP) to get an indication of the R\&D intensity of each region. With these data, we are also able to distinguish between private $\mathrm{R} \& \mathrm{D}$ expenditures done in the business sector $(R \& D-B U S)$, the government sector $(R \& D-G O V)$, and the higher education sector $(R \& D-H E S)$. The latter two we sum together to get an indication of public sector $R \& D$ expenditures $(R \& D-P U B)$.

Figure 1 presents the geographic distribution of both KIBS and R\&D in general. We see a clear and strong spatial clustering of KIBS in urban regions, or at least regions that include a big city or large urban area. This strong urban profile of KIBS is in line with earlier findings that show KIBS' importance in innovation networks, especially in cities (Simmie and Strambach 2006). Regarding R\&D, again urban areas are noticeable but the overall distribution seems more dispersed than KIBS, which is also supported by a somewhat low correlation between the two of about 0.3. Moreover, there seems to be a large group in the core of Europe which has a relatively high $R \& D$ intensity compared to more peripheral regions.

\footnotetext{
3 The following NACE codes refer to KIBS industries: J62, J63, J69, M70.2, M71, M72, M73. Technical-KIBS are J62, J63.11, J63.12, M71.20, and M72 and professional-KIBS are J63.93, J63.99, J69, M70, M71.11, M71.12, and M73.
} 

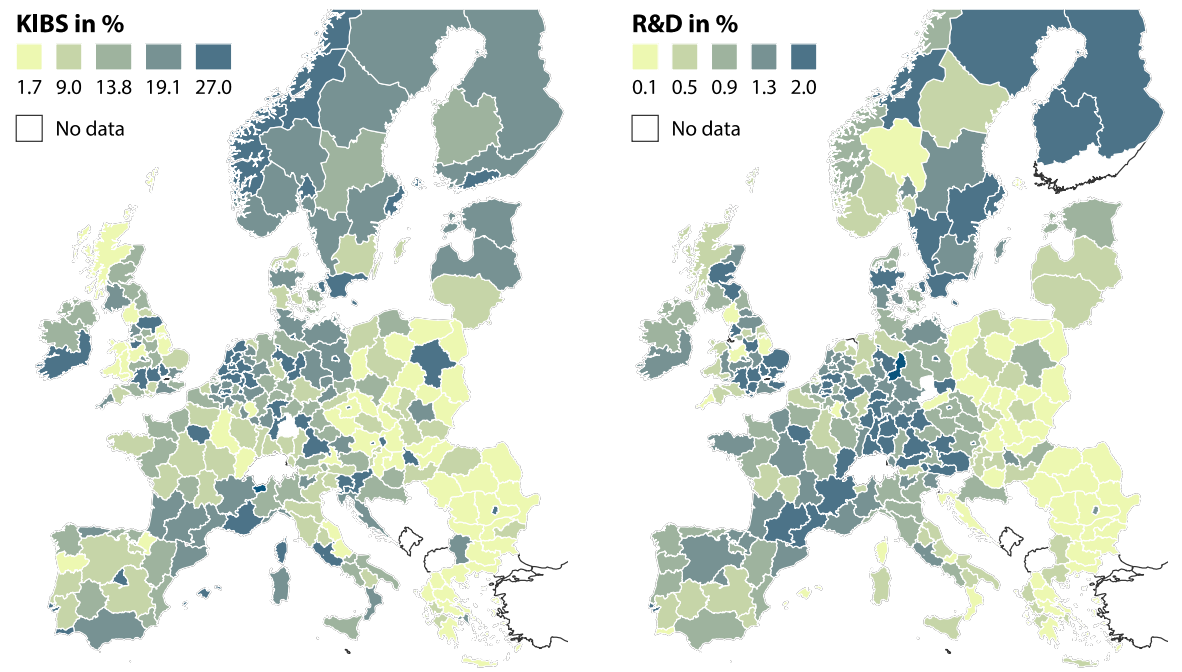

Fig. 1 Geographic distribution of KIBS and R\&D

(A)
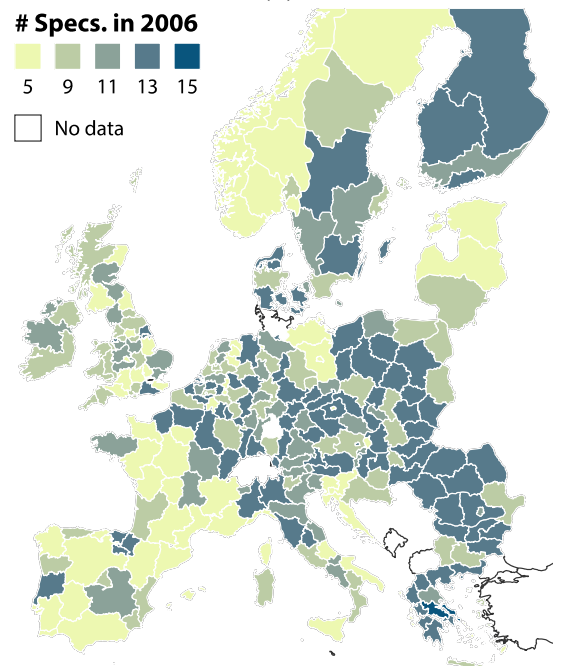

(B)
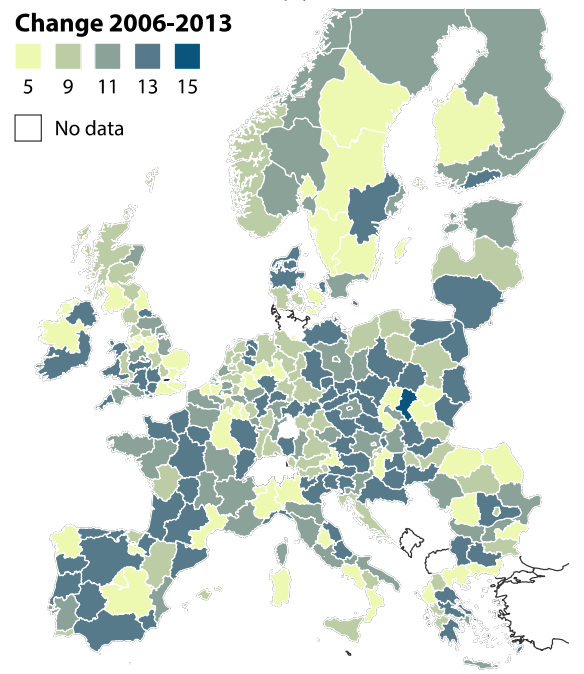

Fig. 2 Geographic distribution of specialisations and change in the number of specialisations

\subsection{Estimation strategy}

We want to analyse whether regional levels of KIBS and R\&D are associated with the propensity of regions to specialise in new industries and whether this helps 
regions to diversify into industries that are less related to industries already present. For this, we first estimate model (1) at the industry level with each observation representing a 4-digit industry of a NUTS-2 region. By using three overlapping 5-year time periods (2006-2011, 2007-2012, 2008-2013), we analyse a 7-year panel in total. As we are interested in what factors are determining a region's ability to develop new specialisations, we exclude those industries that regions were already specialised in at the start of each 5-year time period. The resultant model takes the form of

$$
\begin{aligned}
\mathrm{BLQ}_{i, r, t+5}= & \alpha+\beta_{1} d_{i, r, t}+\beta_{2} \mathrm{KIBS}_{r, t}+\beta_{3} R \& D_{r, t}+\left(\beta_{4} \mathrm{KIBS}_{r, t}+\beta_{5} R \& D_{r, t}\right) * d_{i, r, t} \\
& +{ }^{\prime} \delta^{\prime} C_{r, t}+\theta_{t}+\mu_{i}+\varphi_{r}+\varepsilon_{i, r, t}
\end{aligned}
$$

where $i$ indexes industries, $r$ indexes regions, and $t$ indexes a 5 -year period. Our dependent variable, $B L Q$, is a binary variable, taking the value of 1 if region $r$ is specialised in industry $i$ in $t+5$. Industry density, $d$, indicates the density around each industry, i.e. the extent to which a region is specialised in related industries. ${ }^{4}$ To estimate the impact of $K I B S$ and $R \& D$ on the probability that a region develops new specialisations, we include them directly into out model. We also interact these variables with density to estimate their moderating effect. A negative (positive) moderation effect is interpreted as making a region less (more) reliant on a related type of diversification. Time-, industry-, and region-specific effects are captured by the terms $\theta, \mu$ and $\varphi$, respectively. The random error term, $\varepsilon$, captures the residual of the model.

To assess the impact of KIBS and R\&D on the relatedness of new industrial specialisations more directly, we estimate model (2) only on new specialisations (i.e. only those industries in which regions where not specialised in at $t$ but are specialised in at $t+5)$. This model takes the form of

$$
d_{i, r, t+5}=\alpha+\beta_{1} \mathrm{KIBS}_{r, t}+\beta_{2} R \& D_{r, t}+{ }^{\prime} \delta^{\prime} C_{r, t}+\theta_{t}+\mu_{i}+\varepsilon_{i, r, t}
$$

where the dependent variable, $d_{t+5}$, is relatedness density of new specialisations. A positive (negative) effect of $K I B S$ or $R \& D$ is now interpreted as decreasing (increasing) the relatedness of new specialisations to the already present specialisations.

In the analysis, we also split our $K I B S$ and $R \& D$ variables up into different types of KIBS and R\&D. KIBS are split into technical-KIBS (T-KIBS) and professionalKIBS $(P-K I B S)$, whereas $\mathrm{R} \& \mathrm{D}$ is split up into private sector $\mathrm{R} \& \mathrm{D}(R \& D-B U S)$ and public sector $\mathrm{R} \& \mathrm{D}(R \& D-P U B)$. The latter consists of government sector $\mathrm{R} \& \mathrm{D}(R \& D-G O V)$ and higher education sector $\mathrm{R} \& \mathrm{D}(R \& D-H E S)$. Finally, vector $C$ contains a set of additional control variables (gross regional product per capita, capital formation, population density, and human capital), which we discuss more

\footnotetext{
${ }^{4}$ While a model with a binary dependent variable should ideally be estimated using a Logit or Probit model, the presence of numerous fixed effects makes it problematic and prone to the incidental parameter problem (Greene 2012). We thus follow (Boschma and Capone 2015) and (Cortinovis et al. 2017) and estimate a linear probability model.
} 
Table 1 Estimated impact of Density, KIBS, and R\&D on industry entry probability
(1) $\mathrm{BLQ}_{\mathrm{t}+5}$
(2) $\mathrm{BLQ}_{\mathrm{t}+5}$
(3) $\mathrm{BLQ}_{\mathrm{t}+5}$

(A) Fixed effects and controls

$\begin{array}{llll}\text { Density } & 0.125^{* *} & 0.242^{* *} & 0.242^{* *} \\ \text { lnGRPPC } & (0.011) & (0.019) & (0.019) \\ \text { lnCAPFRM } & & -0.006 \\ & & & (0.006) \\ \text { lnPOPDEN } & & & 0.000 \\ & & & (0.002) \\ \text { lnHC } & & & -0.013 \\ & & & (0.024) \\ \text { Constant } & & & 0.006 * \\ & -0.002+ & -0.013 * * & (0.003) \\ \text { Observations } & (0.001) & (0.002) & 0.090 \\ \text { R-squared } & 219,003 & 219,003 & (0.144) \\ \text { Control vars } & 0.003 & 0.355 & 214,659 \\ \text { Year FE } & \text { No } & \text { No } & 0.357 \\ \text { Region FE } & \text { No } & \text { Yes } & \text { Yes } \\ \text { Industry FE } & \text { No } & \text { Yes } & \text { Yes } \\ \text { No } & \text { Yes } & \text { Yes } \\ \text { No } & & & \text { Yes }\end{array}$

(B) $K I B S$ and $R \& D$

(4) $\mathrm{BLQ}_{\mathrm{t}+5} \quad$ (5) $\mathrm{BLQ}_{\mathrm{t}+5} \quad$ (6) $\mathrm{BLQ}_{\mathrm{t}+5}$

Density

$0.522 * *$

$0.342 * *$

$0.540 * *$

(0.035)

(0.033)

(0.039)

0.064 **

KIBS

0.073 **

(0.020)

(0.022)

$-1.106^{* *}$

KIBS * Density

$-1.116^{* *}$

(0.123)

(0.115)

0.235

$\mathrm{R} \& \mathrm{D}$

$0.525 * *$

(0.151)

R\&D * Density

(0.176)

$-1.270$

$-5.754^{*}$

(1.362)

Constant

$-0.035^{* *}$

$-0.022 * *$

$-0.037 * *$

(0.005)

(0.003)

(0.005)

Observations

198,145

207,582

187,805

R-squared

0.362

0.356

0.362

Control vars

Yes

Yes

Yes

Year FE

Yes

Yes

Yes

Region FE

Yes

Yes

Yes

Industry FE

Yes

Yes

Clustered standard errors in parentheses $(* * p<0.01$,
$* p<0.05,+p<0.1)$ 
elaborately in Sect. 2 of the appendix. Time- and region-specific effects are captured by the terms $\theta$ and $\mu$. The random error term, $\varepsilon$, captures the residual of the model.

\section{Results}

We start by estimating model (1) including only Density as explanatory variable and without the fixed effects. The first column of Table 1. A shows that Density carries a positive and significant coefficient. A one standard deviation increase in Density increases the probability of a region to develop a new specialisation in a 4-digit industry by about 0.6 per cent, ${ }^{5}$ which confirms that the development of new industries is affected by existing industries within the region. Once we control for year-, region-, and industry-fixed effects in column (2) and also include our control variables in column (3), the impact of a one standard deviation change in Density increases substantially to about 1.1 per cent.

Part (B) of Table 1 presents the results when we add our main explanatory variables of interest into the model. Column (4) shows that the level of KIBS has a direct and positive impact on the probability that a region develops new industrial specialisations. Also, KIBS negatively moderate the effect of Density; hence, KIBS is important by making the constraining effect of Density on the creation of new unrelated industries less important. Column (5) shows that the regional level of $R \& D$ positively impacts on the probability that a region develops new specialisations and that the interaction between $R \& D$ and Density exercises a negative moderation effect. Comparing the magnitudes of the estimated effects of KIBS in column (4) and $R \& D$ in column (5), we find that a one standard deviation ${ }^{6}$ increase enhances the probability that a region develops new specialisations by 0.8 and 0.6 per cent for KIBS and $R \& D$ when Density is zero. Density still exercises a strong positive effect after the inclusion of the interaction effects with $K I B S$ and $R \& D$. Figure 3 in Sect. 4 of the appendix depicts the marginal effects of Density at increasing levels of KIBS and $R \& D$. We find that at very low levels of KIBS the magnitude of the effect of Density is at its highest and with increasing levels of KIBS the effect of Density eventually becomes insignificant or even negative. Also with rising levels of $R \& D$, the effect of Density becomes smaller, but at a much lower rate, and it remains positive and significant. When $K I B S$ and $R \& D$ enter the model simultaneously, both the direct and the interaction effects of $R \& D$ become insignificant, while the effects of KIBS decrease slightly.

Table 2 presents the results when we distinguish between different types of KIBS and different sectors for R\&D expenditures. The findings in column (1) show that $T$-KIBS exercises a positive and direct effect on the probability that a region develops a new specialisation, while for $P$-KIBS the effect is insignificant. Both types of KIBS interact negatively with Density. The results reported in column (2) show that the direct effect of $R \& D$ and the interaction effect with Density seem to be driven by

\footnotetext{
5 The standard deviation of Density is 0.46 .

6 The standard deviations of KIBS and $R \& D$ are 0.105 and 0.011 .
} 
Table 2 Estimated impact of different types of KIBS and $R \& D$
(1) $B L Q_{t+5}$

Density

$0.510^{* *}$

(0.037)

$0.092 *$

T-KIBS

(0.040)

P-KIBS

0.025

(0.026)

T-KIBS * Density

$-1.818^{* *}$

$(0.343)$

P-KIBS * Density

$-0.515^{*}$

(0.236)

Constant

$-0.031^{* *}$

$(0.005)$

198,145

Observations

0.362

R-squared

Yes

Yes

Yes

Industry FE

(2) $B L Q_{t+5}$

Density

$0.391 * *$

(0.036)

R\&D-BUS

0.299

(0.244)

R\&D-PUB

$1.197+$

(0.635)

$-2.479$

(2.475)

$-16.85^{* *}$

(5.378)

$-0.026^{* *}$

(0.004)

182,717

0.357

Yes

Yes

Yes

Industry FE Yes

Clustered standard errors in parentheses $(* * p<0.01$, $* p<0.05,+p<0.1)$

Table 6 of appendix presents some additional results and variations in the estimations of model (1) 
Table 3 Estimated impact on Density of new industry specialisations

\begin{tabular}{lllll}
\hline & $(1)^{2}$ Density $_{\mathrm{t}+5}$ & $(2)$ Density $_{\mathrm{t}+5}$ & $(3)$ Density $_{\mathrm{t}+5}$ & $(4)$ Density $_{\mathrm{t}+5}$ \\
\hline KIBS & $-0.169^{* *}$ & & & $-0.281^{* *}$ \\
R\&D & $(0.027)$ & & $(0.042)$ \\
& $0.534^{*}$ & & $-0.941^{*}$ \\
KIBS * R\&D & $(0.220)$ & & $(0.426)$ \\
& & & $7.953^{* *}$ \\
T-KIBS & & & & $(1.938)$ \\
& & & & \\
P-KIBS & & $(0.056)$ & & \\
& & $-0.110^{*}$ & & \\
R\&D-BUS & & $(0.047)$ & & \\
& & & $0.699^{* *}$ & \\
R\&D-PUB & & & $(0.253)$ & \\
& & & $-1.942^{* *}$ & \\
Constant & $0.150^{* *}$ & $0.147^{* *}$ & $(0.735)$ & $0.167^{* *}$ \\
& $(0.005)$ & $(0.005)$ & $(0.005)$ & $(0.007)$ \\
Observations & 2,168 & 2,291 & 1,943 & 2,168 \\
R-squared & 0.509 & 0.480 & 0.479 & 0.527 \\
Year FE & Yes & Yes & Yes & Yes \\
Region FE & No & No & No & No \\
Industry FE & Yes & Yes & Yes & Yes \\
\hline
\end{tabular}

Clustered standard errors in parentheses $\left(* * p<0.01,{ }^{*} p<0.05,+p<0.1\right)$

Table 7 of appendix presents some additional results and variations in the estimations of model (2)

public sector R\&D. ${ }^{7}$ Figure 4 of appendix depicts the interaction effects of these different types of KIBS and R\&D.

We now turn to our second model in which the effect of $K I B S$ and $R \& D$ on the relatedness of new industrial specialisations is estimated more directly. To do so we take as dependent variable Density in $t+5$ and include only those industries in which regions were not specialised in $t$ but have become specialised in $t+5$. Table 3 presents the results of these estimations. We notice from column (1) that KIBS baes a negative sign, indicating that with rising levels of KIBS the relatedness density of industries that a region over time specialises in decreases relative to the industries that the region was already specialised in. The opposite effect is found for $R \& D$, suggesting that $R \& D$ promotes more related industry entries, contrasting our earlier findings in Table 2.

In columns (2) and (3) of Table 3, we split the KIBS and $R \& D$ variables. Regarding $K I B S$, we find that the presence of professional-KIBS has a negative impact on

\footnotetext{
7 The interaction effects of column (6) of Table 1 and both columns of Table 2 are visualised in Fig. 3 of appendix.
} 
the relatedness of new specialisations, while the effect of technical-KIBS is negative but insignificant. The positive effect of $R \& D$ in column (1) seems mainly to be driven by private sector $R \& D$, which results in more related new specialisations. Public sector R\&D on the other hand is strongly associated with a lower relatedness of new industrial specialisations. As $K I B S$ and $R \& D$ have distinct but connected roles in the innovation process of regions, in the last column of Tables 3, 4, 5 we interact the two. We find a positive interaction effect, suggesting that with regard to the relatedness of new industrial specialisations $K I B S$ and $R \& D$ appear to be complementary factors indeed. ${ }^{8}$

\subsection{Robustness tests}

The remaining part of the results section covers some further scrutinising and exploratory types of analyses; full results are presented in Sect. 3, 4, and 5 of the appendix and are concisely discussed here. The first issue concerns the possibility that the effects of $K I B S$ and $R \& D$ may be different across levels of relatedness density. For instance, a region with a limited number of industrial specialisations also has a limited amount of capabilities and knowledge and is therefore at a relative disadvantage to develop both related and unrelated new specialisations. Especially in such regions, it may be the case that the presence of KIBS and R\&D facilitate inflows of capabilities and knowledge. To investigate this, we divide the sample into ten quantiles of relatedness density. We then estimate the effects of $K I B S$ and $R \& D$ using model (2) for each of these groups separately (excluding the lowest and highest groups). The results of this exercise are presented in Fig. 3 and Table 6 of Sect. 3 of the appendix.

We find for $K I B S$ that the effects at different levels of Density are mostly negative and significant but are somewhat stronger in magnitude at medium levels. At very high levels of Density, however, the effect of KIBS becomes insignificant. On the effects of $R \& D$, we find a different pattern: at low and medium levels, we generally find positive effects, while at very high levels of Density a negative effect is estimated.

Secondly, the effects of R\&D up to now are investigated in general or in the private and public sectors individually. However, in our analysis the latter is made up ofgovernment sector and higher education sector R\&D. Tables 7 and 8 of Sect. 4 of the appendix present the results when these sectors are included in the estimations separately. We find that in both estimations of model (1) and model (2), especially $R \& D-G O V$ seems to drive the effect of public R\&D, whereas $R \& D-H E S$ remains insignificant in most of the analyses.

Thirdly, the use of Orbis data allows us to investigate the effects of KIBS presence at a much more fine-grained level than just the division into T-KIBS and P-KIBS. Table 9 of Sect. 4 of the appendix presents two estimations of model (2) in which Density of new specialisations is the dependant variable, one estimation

\footnotetext{
${ }^{8}$ In column (4) of Table 3 the marginal effect of KIBS is $-0.179^{* *}(0.026)$ and of $R \& D$ of is 0.263 $(0.231)$.
} 
Table 4 Summary statistics

\begin{tabular}{llllll}
\hline Variable & Obs & Mean & Std & Min & Max \\
\hline BLQ $_{t}$ & 219,003 & 0 & 0 & 0 & 0 \\
BLQ $_{t+5}$ & 219,003 & 0.011 & 0.102 & 0 & 1 \\
Density & 219,003 & 0.098 & 0.046 & 0.001 & 0.423 \\
KIBS & 219,003 & 0.172 & 0.105 & 0.016 & 0.561 \\
T-KIBS & 219,003 & 0.062 & 0.053 & 0.004 & 0.532 \\
P-KIBS & 219,003 & 0.134 & 0.088 & 0.006 & 0.687 \\
R\&D & 207,582 & 0.013 & 0.011 & 0.001 & 0.066 \\
R\&D-BES & 199,218 & 0.008 & 0.009 & 0.000 & 0.049 \\
R\&D-PUB & 182,717 & 0.005 & 0.004 & 0.000 & 0.021 \\
R\&D-GOV & 185,121 & 0.002 & 0.002 & 0.000 & 0.012 \\
R\&D-HES & 187,821 & 0.003 & 0.002 & 0.000 & 0.015 \\
lnGRPPC & 215,206 & 10.062 & 0.419 & 8.702 & 11.274 \\
lnCAPFRM & 217,631 & 8.851 & 0.955 & 5.017 & 11.834 \\
lnPOPDEN & 215,206 & 4.949 & 1.235 & 1.125 & 9.139 \\
lnHC & 216,282 & 3.093 & 0.373 & 1.917 & 3.877 \\
\hline
\end{tabular}

Table 5 Correlation matrix

\begin{tabular}{|c|c|c|c|c|c|c|c|c|c|c|c|c|c|c|}
\hline & & 1 & 2 & 3 & 4 & 5 & 6 & 7 & 8 & 9 & 10 & 11 & 12 & 13 \\
\hline 1 & $\mathrm{BLQ}_{\mathrm{t}+5}$ & 1 & & & & & & & & & & & & \\
\hline 2 & Density & 0.06 & 1 & & & & & & & & & & & \\
\hline 3 & KIBS & -0.02 & -0.23 & 1 & & & & & & & & & & \\
\hline 4 & T-KIBS & -0.01 & -0.11 & 0.81 & 1 & & & & & & & & & \\
\hline 5 & P-KIBS & -0.01 & -0.23 & 0.65 & 0.34 & 1 & & & & & & & & \\
\hline 6 & $\mathrm{R} \& \mathrm{D}$ & 0.00 & 0.09 & 0.30 & 0.31 & 0.42 & 1 & & & & & & & \\
\hline 7 & R\&D-BES & 0.00 & 0.11 & 0.21 & 0.24 & 0.38 & 0.95 & 1 & & & & & & \\
\hline 8 & R\&D-PUB & 0.00 & -0.01 & 0.40 & 0.36 & 0.33 & 0.70 & 0.46 & 1 & & & & & \\
\hline 9 & R\&D-GOV & 0.00 & -0.01 & 0.39 & 0.34 & 0.36 & 0.54 & 0.34 & 0.78 & 1 & & & & \\
\hline 10 & R\&D-HES & 0.00 & -0.01 & 0.28 & 0.26 & 0.21 & 0.62 & 0.41 & 0.86 & 0.36 & 1 & & & \\
\hline 11 & $\operatorname{lnGRPPC}$ & -0.01 & -0.06 & 0.55 & 0.49 & 0.49 & 0.48 & 0.44 & 0.38 & 0.26 & 0.36 & 1 & & \\
\hline 12 & lnCAPFRM & -0.01 & 0.14 & 0.27 & 0.24 & 0.32 & 0.50 & 0.45 & 0.41 & 0.32 & 0.35 & 0.50 & 1 & \\
\hline 13 & InPOPDEN & 0.00 & 0.08 & 0.23 & 0.26 & 0.28 & 0.23 & 0.20 & 0.19 & 0.24 & 0.09 & 0.20 & 0.32 & 1 \\
\hline 14 & $\ln \mathrm{HC}$ & -0.01 & -0.16 & 0.44 & 0.28 & 0.46 & 0.47 & 0.40 & 0.45 & 0.35 & 0.39 & 0.54 & 0.35 & 0.13 \\
\hline
\end{tabular}

with 2-digit KIBS employment shares as explanatory variables and one estimation with 4-digit KIBS employment shares as explanatory variables. The first estimation with 2-digit level KIBS shares provides some more insight: For legal and accounting activities (69) and architectural and engineering activities (71), we find strong negative effects on the relatedness density of new specialisations. For advertising and market research (73), we find a positive effect. The second estimation includes 4-digit level KIBS shares, here we find a negative effect for: other information service activities (6399), legal activities (6910), accounting, bookkeeping, auditing, 
and tax consultancy (6920), business and other management consultancy activities (7022), engineering activities and technical consultancy (7112), and technical testing and analysis (7120). For research and development on biotechnology (7211) we find a positive effect.

Fourthly, KIBS presence is often ascribed a highly urban profile that indeed also appears in Fig. 1. The positive association that we find between KIBS and the rise of (unrelated) specialisations in a region may therefore be influenced to some extent by urban regions in the sample. Although we control for regional fixed effects, the average effect of KIBS may still be driven by regions containing a big city or urban area with characteristics that contribute to the attraction of unrelated capabilities and knowledge. Table 10 of Sect. 4 of the appendix presents a robustness analysis in which we take this into account by interacting $K I B S$ (and also $R \& D$ ) with a dummy variable capturing whether or not a region contains a big city. The results show that the effects of KIBS then become rather small and that the effects of KIBS could certainly be driven by regions other than those containing a big city to some extent. The effect of KIBS in cities may thus be diluted by all kinds of urbanisation effects; nevertheless, our results show that KIBS have a significant effect on the relatedness of new specialisations in regions that do not contain a substantial urban area.

Lastly, in determining whether a region is specialised in a particular industry, cutoff points for each 4-digit industry's location quotient are calculated using a bootstrapping procedure. This has the benefit that we can statistically determine relevant cut-off points and implicitly take into account some industry differences, but it also comes at a cost. For instance, some regions could have a large number of employees occupied in a particular industry; however, the possibility exists that they are not employed for the most relevant activities within that particular industry. Such a region would in our procedure be highly specialised in that industry, with the bootstrapping procedure perhaps increasing the chances of such an event to occur. As a robustness test we also estimate models (1) and (2) on a sample without using bootstrapping to determine relevant cut-off points. Instead we take location quotient $>1$ as the cut-off point.

Table 11 of Sect. 5 of the appendix depicts the results of this exercise. In the case of model (1), we first observe that the resulting sample now includes about 175.000 observations (i.e. industries regions where not specialised in at $t$ ). Using 1 as cut-off point thus yields more industrial specialisations at the start of our sample, as the number of industries regions can still specialise in is decreased. The sample used for model (2) increases to about 6.000 observations (i.e. industries regions where not specialised in at $t$ but are specialised in at $t+5)$. Regarding the effects of $K I B S$ and $R \& D$, in model (1) they turn insignificant while in model (2) they stay roughly the same.

\section{Conclusions and policy recommendations}

Recent studies in the field of evolutionary economic geography demonstrate that new economic activities in regions often branch-out of already established activities. As a result, new economic activities are related to established activities and 
because diversification into related activities is more efficiently realised, industrial diversification can become highly path-dependent, making it difficult for regions to structurally renew their industrial profiles. For regional economies to attain sustainable prosperity and resilience in the long run, it is therefore necessary to develop unrelated activities from time to time to support new development trajectories.

Two conditions can be identified that can help to offset the forces of path-dependant growth. For this, new economic activities need to be developed that rely on different and unrelated sets of knowledge and capabilities. The first condition discussed by recent literature concerns how the presence of extra-regional linkages can provide inflows of unrelated knowledge. The second condition that we propose in this study concerns bridges or networks within an economy that can connect both related and unrelated firms (but also universities, research institutes, and governments) through which knowledge spillovers between unrelated actors may be facilitated. In this study we investigate whether the presence of KIBS and R\&D may be factors that can supply a region with these conditions.

Our results indicate that these factors support the emergence of new industrial specialisations as well as moderate the path-dependency effects of relatedness, which we interpret as KIBS and R\&D being able to compensate for a lack of local related knowledge and capabilities. More specifically, we find that the presence of technical-KIBS has a stronger effect on the rise of new industrial specialisations than the presence of professional-KIBS has. However, when the relatedness of new emerging industrial specialisations is analysed more directly, we find that is especially professional-KIBS that are associated with less related new specialisations. The effect of R\&D in this sense is more ambiguous. Interestingly, R\&D stemming from the private sector increases the relatedness of new specialisations and R\&D stemming from the public sector strongly decreases the relatedness of new specialisations.

Additional results from dividing the sample into quantiles of relatedness density show that the effect of KIBS on the relatedness of new specialisation in general is negative but especially so at medium levels of relatedness density, turning insignificant at very high levels of relatedness density. The effect of $R \& D$ is in general positive but becomes negative at very high levels of relatedness density. Furthermore, when public $R \& D$ it split up into government and higher education $R \& D$, we find that the effect of public R\&D is primarily driven by government sector R\&D. When the effects of R\&D and KIBS on the relatedness of new specialisations are investigated in regions containing a big city, we find that the effect of KIBS in big cities is very small. Regarding $R \& D$ in cities, we find that the positive effect of private $R \& D$ is decreased slightly but the negative effect of public R\&D is amplified.

While these findings advance our understanding of how regions can acquire new unrelated knowledge and capabilities to foster industrial diversification, they also bear important implications for policy makers. As for instance emphasised by the Smart Specialisation Strategy of the European Commission, policy makers should acknowledge that regions cannot do everything but instead should build upon the assets and resources readily available to the region. Therefore, not all regions should focus on the invention of new General-Purpose Technologies (GPTs), but rather the majority of the R\&D and innovation efforts should focus on new applications of 
such GPTs in other parts of the economy based on what capabilities and knowledge are already available within the region. Furthermore, Smart Specialisation highlights the role of an entrepreneurial discovery process, in which entrepreneurs (defined here in a broad sense to include, besides individual inventors, also firms, higher education institutions, and innovators in general) are key to the discovery of potential domains for development, as they are able to combine scientific and technological knowledge with knowledge about market growth potential and potential competitors (Foray et al. 2009).

Although the Smart Specialisation Strategy emphasises the importance of building upon assets and resources readily available to the region, when it comes to industrial diversification it is important that regions from time to time rely less on already existing (related) knowledge and capabilities in the development of new economic activities (e.g. Boschma 2015; Simmie and Martin 2010). As new activities within a region are expected to arise from the recombination of already existing local (related) knowledge, policies that aim to reinforce a regions' assets and resources therefore in the long run increase the risk of regions ending up in technological lock-ins, potentially with detrimental effects for employment and prosperity. Instead, policy makers are advised to take into account a long-term perspective by finding the right balance between exploiting less risky policies of related diversification with examining what conditions are available or can feasibly be developed that can compensate for lacking related capabilities. With respect to the latter, two conditions enable regional economies to acquire new unrelated knowledge and capabilities: (1) conditions that provide external linkages for the inflow of knowledge, and (2) conditions that act as a bridge between unrelated actors by facilitating knowledge spillovers between them. Next to the presence of KIBS and investment in R\&D that is the focus of this study, other factors may offer such conditions.

Regarding KIBS, their function as external source of knowledge in particular enables them to facilitate knowledge spillovers between a diverse and sometimes unrelated or non-local set of actors (such as firms, governments, or research institutes). What is more, due to their central position between these actors and their ability to combine and transfer knowledge, KIBS can bring together different types of knowledge (e.g. about technology, markets, or regulation), fostering an entrepreneurial discovery process as intended by the Smart Specialisation Strategy.

Policies aimed at increasing the presence of KIBS only, however, may turn out less effective, as the growth of KIBS is primarily driven by demand. In addition, besides such an approach, policies may need to be developed that enhance the accessibility of KIBS in general but especially for firms that are less able in acquiring new knowledge or transforming this new knowledge into economic solutions. A combination of such demand and supply focused instruments is more likely to foster an entrepreneurial discovery process that identifies efficiently possible directions for future specialisation (Janssen and Castaldi 2018).

With regard to fostering incremental innovation by $R \& D$, generic $R \& D$ subsidies are expected to support the development of related innovation domains (Frenken 2017). Subsidising those R\&D efforts that specifically focus on the 
development of new applications of GPTs may therefore increase the additionality of these policies. For breakthrough innovations, the promotion of recombining previously unrelated knowledge domains is necessary, subsequently making the knowledge domains more related. Our findings suggest that public R\&D is more likely to support this type of innovation, while private sector R\&D is less likely to direct its efforts to support this type of innovation. Furthermore, entrepreneurial activity is hampered by increasing cognitive distances (Content et al. 2019), as entrepreneurs in such cases are less able to understand and investigate possible ways of exploiting business possibilities by relating previously unrelated knowledge domains.

Especially with regard to fostering breakthrough innovations, one possibility would be to support cross-specialisations that connect presently unrelated technologies or industries. This may result in innovations on which sustained comparative advantages can be build, as such innovations are hard to imitate (Janssen and Frenken 2019). Such cross-specialisations, however, do not necessarily have to be sought for within the same region. The best possibilities for crossspecialisations may cross regional boundaries, suggesting that supporting R\&D collaboration platforms can therefore be a fertile destination for R\&D (Janssen 2019).

\section{Appendix 1: Industry specialisation and relatedness}

A common approach to estimating inter-industry relatedness is to use a proximity index, originally developed by Hidalgo et al. (2007). By using international trade data, the authors calculate whether a country has a comparative advantage in exporting a good and the probability that this good is exported with comparative advantage simultaneously with another good. With rising probability of a country exporting a set of goods with a comparative advantage simultaneously, relatedness is assumed to rise as well. The argument for this approach is that related industries or goods would require similar capabilities. In contrast to Hidalgo et al. (2007), a number of studies have replicated this approach not at the national level but at the regional level (Boschma et al. 2013; Cortinovis et al. 2017; Essletzbichler 2015; Neffke et al. 2011). Instead of using trade data to establish a comparative advantage in a good or industry, these studies have used employment data to establish whether regions, relatively to other regions in the sample, are more or less specialised in an industry. We follow those studies and use the location quotient to determine whether a region is specialised in a particular industry using

$$
L Q_{i, r}=\frac{E_{i, r} / E_{r}}{E_{i} / E}
$$

where $i$ and $r$ index industries and regions, respectively. $E$ represents the sum of employment in either all industries of all regions, one industry in all regions, one region in all industries, or one industry in one region. When $L Q_{i r}$ equals 1 , the share of industry $i$ in region $r$ is equal to the average share of that industry in all regions 
in our sample. A common way to define whether a region is specialised in a certain industry is to set not specialised to range from 0 to 1 , and specialised to range from 1 and above. However, as a $L Q$ of 1 can mean different things depending on the characteristics of industries, some have criticised the use of 1 as cut-off point when using location quotients (Guimarães et al. 2009).

In this study, we use a bootstrapping method to statistically determine relevant cut-off points for each 4-digit industry. For this we first standardise the location coefficient using

$$
S L Q_{i, r}=\frac{L Q_{i, r}-\overline{L Q_{i}}}{s d\left(L Q_{i}\right)}
$$

where $\overline{\mathrm{LQ}_{\mathrm{i}}}$ is the average $L Q$ of industry $i$ and $s d\left(L Q_{i}\right)$ is the standard deviation of $L Q$ for industry $i$. We then proceed to bootstrap $S Q L$ for each 4-digit industry 1000 times and take the mean value of the $95^{\text {th }}$ percentile of all bootstrap samples as the critical cut-off point. Finally, we define a region to be specialised in a certain industry when $S L Q_{i r}$ is above the critical bootstrap value.

Once we know in which industries a region is specialised, we can calculate inter-industry relatedness based on the co-occurrence of specialisations. We follow Hidalgo et al. (2007) and assume that when the probability of being specialised rises so does it relatedness. Accordingly, we define our proximity index as

$$
\varphi_{i, j}=\min \left\{P\left(B L Q_{i} \mid B L Q_{j}\right), P\left(B L Q_{j} \mid B L Q_{i}\right)\right\}
$$

The result of this transformation is a $283 \times 283$ matrix, in which each cell refers to the minimum conditional probability of a region being specialised in industry $i$ given that it is specialised in industry $j$. BLQ is our binary location quotient, which is 1 if region $r$ is specialised in industry $i$ and 0 otherwise. Proximity between a set of industries is higher when regions are more often specialised in them together because they require similar capabilities, technologies, social networks, institutions, infrastructure, etc. Following Hausmann and Klinger (2007), the next step is to calculate industry density as

$$
\mathrm{d}_{i, r}=\left(\frac{\sum_{j} \varphi_{i, j} B L Q_{j, r}}{\sum_{j} \varphi_{i, j}}\right)
$$

where $\varphi$ represents proximity as shown in Eq. 5, between industry $i$ and $j$. Again, $B L Q$ is our binary location quotient. The resulting density measure, $d_{i r}$, gives an indication of how much of the related industries a region is specialised in, relative to a certain reference industry $i$. It ranges from 0 to 1 , where 0 indicates a region is not specialised in any of the related industries and 1 indicates it is specialised in all of the related industries. 
Figure 2 shows the spatial distribution of the dependent variable as the initial number of industrial specialisations of regions in 2006 and the change in the number of specialisations from 2006 to 2013. Especially noticeable is the relatively low number of specialisations in regions in Norway, the Baltic states, southern France, and parts of Spain. Looking at the change in the number of specialisations the picture looks slightly more fragmented.

\section{Appendix 2: Descriptive statistics and control variables}

In order to account for other factors that might influence a region's propensity to develop new industrial specialisations, we include several control variables in our models. Earlier studies have shown that more developed and richer economies have a higher probability to develop new specialisations due to increased opportunities for recombination (Hidalgo and Hausmann 2009). Therefore, to control for the overall level of economic development of regions we include the gross regional product per capita $(G R P P C)$. To control for the overall level of urbanisation, we include population density (POPDEN). As human and physical capital might support the development of new industry activities, gross capital formation (CAPFRM) and tertiary educational attainment $(H C)$ are also included in the model. Information to construct these variables is retrieved from Eurostat at the NUTS-2 level for the years 2006, 2007, and 2008. All of these variables enter our specifications in logarithms. Tables 4 and 5 provide summary statistics and a correlation matrix for these and other variables used in this study.

\section{Appendix 3: Analysis across quantiles of relatedness density}

The effects of $K I B S$ and $R \& D$ may be different across levels of relatedness density. For instance, a region with a limited number of specialised activities is likely to have a limited amount of capabilities and knowledge and is therefore at a relative disadvantage to develop both related and unrelated new specialisations. Especially in such regions it may be the case that the presence of KIBS and R\&D expenditure provide ways for an inflow of external knowledge. To further investigate this, we divide the sample into ten quantiles of relatedness density. We then estimate the effects of $K I B S$ and $R \& D$ on the probability that a region develops a new specialisation for each of these groups separately.

The results of this exercise are presented in Fig. 4 and Table 8 of appendix. The sample is divided into 10 groups based on the value relatedness density and before 


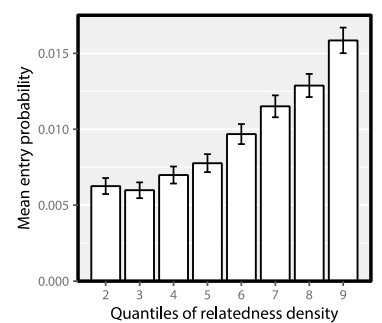

(A)

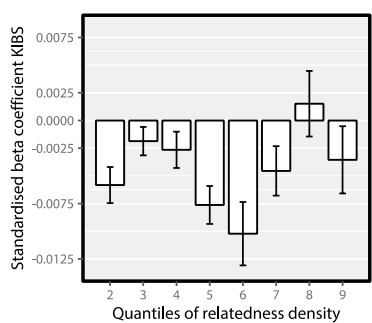

(B)

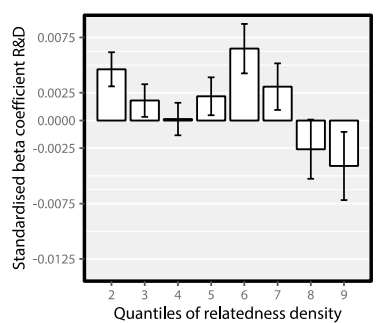

(C)

Fig. 3 Mean entry probability and effects of KIBS and R\&D across quantiles of density

the estimations the lowest and highest quantiles are excluded in order to avoid issues stemming from extremely low or high values of density. Panel (A) of Fig. 3 depicts the mean entry probability across quantiles of relatedness density. We clearly see that with rising levels of relatedness density, so rises the mean entry probability of industries.

Panels (B) and (C) depict the estimated beta coefficients of KIBS and $R \& D$. Starting with $K I B S$, we mostly find negative and significant effects that are somewhat stronger in magnitude at medium levels of Density. At very high levels of Density, however, the effect of $K I B S$ becomes insignificant. On the effects of $R \& D$ we find a different pattern, at low and medium levels we generally find positive effects, while at very high levels of Density a positive effect is estimated.

At very high levels of relatedness density (quantiles 8 and 9), the chances of path dependence may increase, as a region could become overly locked-in a definite range of related tasks or industries. At such levels, both $K I B S$ and $R \& D$ do not seem to have a significant role in the relatedness of new specialisations. Regarding KIBS, one explanation could be that the knowledge-intensive departments of KIBS providers themselves are subdivided into various sections, impeding unrelated within-firm knowledge spillovers that in turn impede the efficiency by which KIBS providers can support unrelated knowledge spillovers within a region (Table 6). 
Table 6 Effects of KIBS and R\&D across different quantiles of relatedness density

\begin{tabular}{|c|c|c|c|c|c|c|c|c|}
\hline Quantile & (2) & (3) & (4) & (5) & (6) & (7) & (8) & (9) \\
\hline \multicolumn{9}{|l|}{ (A) } \\
\hline KIBS (std) & $\begin{array}{l}-0.006^{* *} \\
(0.002)\end{array}$ & $\begin{array}{l}-0.002 \\
(0.001)\end{array}$ & $\begin{array}{l}-0.003 \\
(0.002)\end{array}$ & $\begin{array}{l}-0.008^{* *} \\
(0.002)\end{array}$ & $\begin{array}{l}-0.010^{* *} \\
(0.003)\end{array}$ & $\begin{array}{l}-0.005^{*} \\
(0.002)\end{array}$ & $\begin{array}{l}0.002 \\
(0.003)\end{array}$ & $\begin{array}{l}-0.004 \\
(0.003)\end{array}$ \\
\hline $\mathrm{R} \& \mathrm{D}$ (std) & $\begin{array}{l}0.005 * * \\
(0.002)\end{array}$ & $\begin{array}{l}0.002 \\
(0.001)\end{array}$ & $\begin{array}{l}0.000 \\
(0.001)\end{array}$ & $\begin{array}{l}0.002 \\
(0.002)\end{array}$ & $\begin{array}{l}0.006 * * \\
(0.002)\end{array}$ & $\begin{array}{l}0.003 \\
(0.002)\end{array}$ & $\begin{array}{l}-0.003 \\
(0.003)\end{array}$ & $\begin{array}{l}-0.004 \\
(0.003)\end{array}$ \\
\hline $\begin{array}{l}\text { Observa- } \\
\text { tions }\end{array}$ & 184 & 182 & 189 & 181 & 186 & 178 & 176 & 178 \\
\hline $\begin{array}{l}\text { R-squared } \\
\text { (B) }\end{array}$ & 0.336 & 0.640 & 0.427 & 0.547 & 0.500 & 0.561 & 0.554 & 0.522 \\
\hline $\begin{array}{l}\text { T-KIBS } \\
\text { (std) }\end{array}$ & $\begin{array}{l}-0.002 \\
(0.002)\end{array}$ & $\begin{array}{l}-0.003+ \\
(0.002)\end{array}$ & $\begin{array}{l}-0.002 \\
(0.002)\end{array}$ & $\begin{array}{l}-0.005^{*} \\
(0.003)\end{array}$ & $\begin{array}{l}-0.004 \\
(0.003)\end{array}$ & $\begin{array}{l}-0.008 * * \\
(0.003)\end{array}$ & $\begin{array}{l}0.004 \\
(0.004)\end{array}$ & $\begin{array}{l}0.001 \\
(0.003)\end{array}$ \\
\hline $\begin{array}{l}\text { P-KIBS } \\
\text { (std) }\end{array}$ & $\begin{array}{l}0.002 \\
(0.002)\end{array}$ & $\begin{array}{l}0.006 * * \\
(0.002)\end{array}$ & $\begin{array}{l}0.001 \\
(0.002)\end{array}$ & $\begin{array}{l}-0.005+ \\
(0.003)\end{array}$ & $\begin{array}{l}-0.003 \\
(0.004)\end{array}$ & $\begin{array}{l}0.002 \\
(0.003)\end{array}$ & $\begin{array}{l}-0.002 \\
(0.003)\end{array}$ & $\begin{array}{l}0.002 \\
(0.004)\end{array}$ \\
\hline $\begin{array}{l}\text { R\&D-BUS } \\
\text { (std) }\end{array}$ & $\begin{array}{l}0.003+ \\
(0.002)\end{array}$ & $\begin{array}{l}0.007 * * \\
(0.002)\end{array}$ & $\begin{array}{l}0.000 \\
(0.002)\end{array}$ & $\begin{array}{l}0.000 \\
(0.002)\end{array}$ & $\begin{array}{l}0.007 * \\
(0.003)\end{array}$ & $\begin{array}{l}-0.003 \\
(0.003)\end{array}$ & $\begin{array}{l}-0.004 \\
(0.004)\end{array}$ & $\begin{array}{l}-0.006+ \\
(0.003)\end{array}$ \\
\hline $\begin{array}{l}\text { R\&D-PUB } \\
\text { (std) }\end{array}$ & $\begin{array}{l}-0.002 \\
(0.002)\end{array}$ & $\begin{array}{l}-0.005^{* *} \\
(0.002)\end{array}$ & $\begin{array}{l}0.001 \\
(0.002)\end{array}$ & $\begin{array}{l}0.003 \\
(0.002)\end{array}$ & $\begin{array}{l}-0.000 \\
(0.003)\end{array}$ & $\begin{array}{l}0.008 * * \\
(0.002)\end{array}$ & $\begin{array}{l}0.000 \\
(0.003)\end{array}$ & $\begin{array}{l}-0.006^{*} \\
(0.003)\end{array}$ \\
\hline $\begin{array}{l}\text { Observa- } \\
\text { tions }\end{array}$ & 153 & 158 & 175 & 162 & 165 & 159 & 160 & 165 \\
\hline R-squared & 0.388 & 0.691 & 0.432 & 0.553 & 0.498 & 0.618 & 0.536 & 0.578 \\
\hline
\end{tabular}

Clustered standard errors in parentheses $\left(* * p<0.01,{ }^{*} p<0.05,+p<0.1\right)$. Depend variable: $\mathrm{BLQ}_{\mathrm{t}+5}$. The results presented in this tabel were obtained afer dividing our sample into 10 different groups, based the level of relatedness density. We estimated our model twice, once including KIBS and R\&D as main explanatory variables and once including T-KIBS, P-KIBS, R\&D-BUS, and R\&D-PUB as main explanatory variables. The main explanatory variables are standardised to have a mean of 0 and a standard deviation of 1 to make the beta coefficients directly comparable. The estimations also included the other control variables and, year-, and industry-specific effects. We excluded the lowest and highest quantiles, resulting in 8 groups of observations 


\section{Appendix 4: Supportive and additional results}

See Fig. 4 and Tables 7, 8, 9, 10

(A)

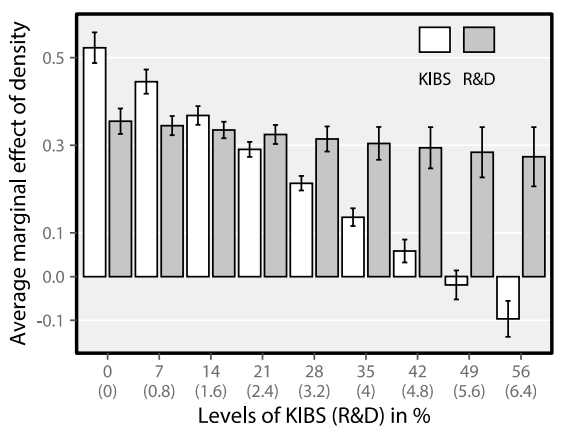

(C)

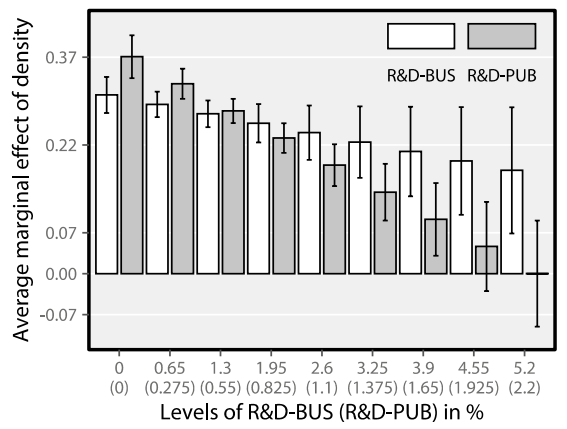

Fig. 4 Average marginal effects of KIBS and R\&D
(B)

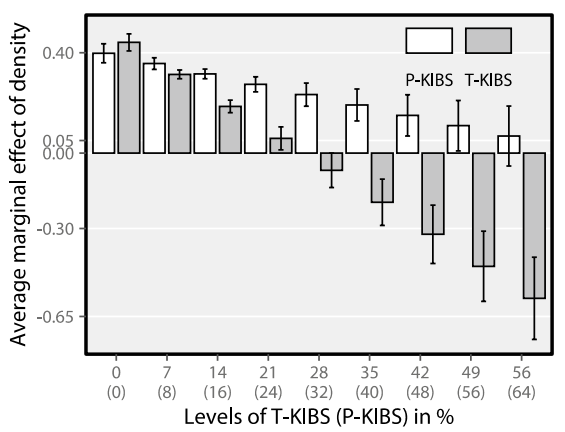

These figures present the average marginal effects of Density across different levels of KIBS and $R \& D$. The results are taken from the estimations presented in tables 1 and 2. Panel (A) corresponds to column (6) of table 1. Panel (B) corresponds to column (1) of table 2 and panel $(C)$ corresponds to column (2) of table 2. 
Table 7 Estimated impact of different types of KIBS and $\mathrm{R} \& \mathrm{D}$

\begin{tabular}{|c|c|c|c|}
\hline & (1) $\mathrm{BLQ}_{\mathrm{t}+5}$ & (2) $\mathrm{BLQ}_{\mathrm{t}+5}$ & (3) $\mathrm{BLQ}_{t+5}$ \\
\hline Density & $\begin{array}{l}0.527 * * \\
(0.045)\end{array}$ & $\begin{array}{l}0.445 * * \\
(0.040)\end{array}$ & $\begin{array}{l}0.521 * * \\
(0.045)\end{array}$ \\
\hline T-KIBS & $\begin{array}{l}0.104 * \\
(0.047)\end{array}$ & & $\begin{array}{l}0.104 * \\
(0.047)\end{array}$ \\
\hline P-KIBS & $\begin{array}{l}0.011 \\
(0.029)\end{array}$ & & $\begin{array}{l}0.009 \\
(0.029)\end{array}$ \\
\hline T-KIBS * Density & $\begin{array}{l}-2.043^{* *} \\
(0.446)\end{array}$ & & $\begin{array}{l}-2.047 * * \\
(0.447)\end{array}$ \\
\hline P-KIBS * Density & $\begin{array}{l}-0.417 \\
(0.322)\end{array}$ & & $\begin{array}{l}-0.370 \\
(0.325)\end{array}$ \\
\hline R\&D-BES & $\begin{array}{l}0.133 \\
(0.200)\end{array}$ & $\begin{array}{l}0.503+ \\
(0.269)\end{array}$ & $\begin{array}{l}0.186 \\
(0.218)\end{array}$ \\
\hline R\&D-PUB & $\begin{array}{l}-0.113 \\
(0.625)\end{array}$ & & \\
\hline R\&D-BES * Density & $\begin{array}{l}0.713 \\
(2.036)\end{array}$ & $\begin{array}{l}-3.955 \\
(2.910)\end{array}$ & $\begin{array}{l}0.095 \\
(2.335)\end{array}$ \\
\hline R\&D-PUB * Density & $\begin{array}{l}-1.590 \\
(5.401)\end{array}$ & & \\
\hline R\&D-GOV & & $\begin{array}{l}2.985 * * \\
(1.012)\end{array}$ & $\begin{array}{l}0.932 \\
(0.849)\end{array}$ \\
\hline R\&D-HES & & $\begin{array}{l}-0.172 \\
(1.050)\end{array}$ & $\begin{array}{l}-1.004 \\
(1.045)\end{array}$ \\
\hline R\&D-GOV * Density & & $\begin{array}{l}-31.112^{* *} \\
(8.686)\end{array}$ & $\begin{array}{l}-6.573 \\
(6.718)\end{array}$ \\
\hline R\&D-HES * Density & & $\begin{array}{l}-6.736 \\
(9.349)\end{array}$ & $\begin{array}{l}2.965 \\
(8.906)\end{array}$ \\
\hline Constant & $\begin{array}{l}-0.032 * * \\
(0.005)\end{array}$ & $\begin{array}{l}-0.030 * * \\
(0.005)\end{array}$ & $\begin{array}{l}-0.031 * * \\
(0.006)\end{array}$ \\
\hline Observations & 165,328 & 165,328 & 165,328 \\
\hline R-squared & 0.354 & 0.353 & 0.354 \\
\hline Year FE & Yes & Yes & Yes \\
\hline Region FE & Yes & Yes & Yes \\
\hline Industry FE & Yes & Yes & Yes \\
\hline
\end{tabular}


Table 8 Estimated impact on Density of new industry specialisations

\begin{tabular}{|c|c|c|c|c|c|c|}
\hline \multirow{3}{*}{$\overline{\mathrm{T}-\mathrm{KIBS}}$} & \multirow{2}{*}{$\begin{array}{l}\text { (1) } \\
\text { Density }_{t+5}\end{array}$} & \multirow{2}{*}{$\begin{array}{l}\text { (2) } \\
\text { Marg. eff }\end{array}$} & \multicolumn{4}{|l|}{ (3) } \\
\hline & & & Density $_{t+5}$ & Marg. eff & Density $_{t+5}$ & Marg. eff \\
\hline & $\begin{array}{l}-0.115^{*} \\
(0.057)\end{array}$ & $\begin{array}{l}-0.036 \\
(0.039)\end{array}$ & & & & \\
\hline P-KIBS & $\begin{array}{l}-0.327 * * \\
(0.045)\end{array}$ & $\begin{array}{l}-0.23^{* *} \\
(0.034)\end{array}$ & & & & \\
\hline $\mathrm{R} \& \mathrm{D}$ & $\begin{array}{l}-1.006^{*} \\
(0.417)\end{array}$ & $\begin{array}{l}0.226 \\
(0.260)\end{array}$ & & & & \\
\hline T-KIBS $*$ R\&D & $\begin{array}{l}6.082 * \\
(2.859)\end{array}$ & & & & & \\
\hline $\mathrm{P}-\mathrm{KIBS} * \mathrm{R} \& \mathrm{D}$ & $\begin{array}{l}7.519 * * \\
(1.099)\end{array}$ & & & & & \\
\hline KIBS & & & $\begin{array}{l}-0.306^{* *} \\
(0.053)\end{array}$ & $\begin{array}{l}-0.17 * * \\
(0.030)\end{array}$ & $\begin{array}{l}-0.298 * * \\
(0.054)\end{array}$ & $\begin{array}{l}-0.17 * * \\
(0.030)\end{array}$ \\
\hline R\&D-BUS & & & $\begin{array}{l}-0.192 \\
(0.446)\end{array}$ & $\begin{array}{l}0.600 * \\
(0.244)\end{array}$ & $\begin{array}{l}-0.445 \\
(0.502)\end{array}$ & $\begin{array}{l}0.703 * * \\
(0.253)\end{array}$ \\
\hline R\&D-PUB & & & $\begin{array}{l}-4.123^{*} \\
(1.880)\end{array}$ & $\begin{array}{l}-1.268 \\
(0.904)\end{array}$ & & \\
\hline R\&D-BUS * KIBS & & & $\begin{array}{l}5.371^{*} \\
(2.358)\end{array}$ & & $\begin{array}{l}7.786 * * \\
(2.827)\end{array}$ & \\
\hline R\&D-PUB * KIBS & & & $\begin{array}{l}19.370^{*} \\
(8.262)\end{array}$ & & & \\
\hline R\&D-GOV & & & & & $\begin{array}{l}-8.823^{*} \\
(3.526)\end{array}$ & $\begin{array}{l}-2.391 \\
(1.840)\end{array}$ \\
\hline R\&D-HES & & & & & $\begin{array}{l}-0.395 \\
(2.677)\end{array}$ & $\begin{array}{l}-0.925 \\
(1.098)\end{array}$ \\
\hline R\&D-GOV * KIBS & & & & & $\begin{array}{l}43.638 * * \\
(13.384)\end{array}$ & \\
\hline R\&D-HES * KIBS & & & & & $\begin{array}{l}-3.597 \\
(13.086)\end{array}$ & \\
\hline Constant & $\begin{array}{l}0.169 * * \\
(0.007)\end{array}$ & & $\begin{array}{l}0.176^{* *} \\
(0.010)\end{array}$ & & $\begin{array}{l}0.174 * * \\
(0.010)\end{array}$ & \\
\hline Observations & 2168 & & 1943 & & 1943 & \\
\hline R-squared & 0.536 & & 0.543 & & 0.549 & \\
\hline Year FE & Yes & & Yes & & Yes & \\
\hline Region FE & No & & No & & No & \\
\hline Industry FE & Yes & & Yes & & Yes & \\
\hline
\end{tabular}

Clustered standard errors in parentheses $\left(* * p<0.01,{ }^{*} p<0.05,+p<0.1\right)$. Additional estimations of variations of model (2). Both the estimated beta coefficients and the marginal effects (marg. eff.) of the main explanatory variables are reported 
Table 9 Effects of KIBS on new industrial specialisations at 3 and 4 digits

\begin{tabular}{|c|c|c|c|c|c|}
\hline \multirow[b]{2}{*}{ Computer programming, consultancy and related activities } & \multirow[b]{2}{*}{62} & \multicolumn{2}{|c|}{ (1) Density ${ }_{t+5}$} & \multicolumn{2}{|c|}{ (2) Density t $_{t+5}$} \\
\hline & & 0.022 & $(0.074)$ & & \\
\hline Computer programming activities & 6201 & & & -0.019 & $(0.098)$ \\
\hline Computer consultancy activities & 6202 & & & -0.003 & $(0.138)$ \\
\hline Computer facilities management activities & 6203 & & & 0.414 & $(0.254)$ \\
\hline Other information technology and computer service activities & 6209 & & & -0.178 & $(0.130)$ \\
\hline Information service activities & 63 & -0.237 & $(0.224)$ & & \\
\hline Data processing, hosting and related activities & 6311 & & & -0.032 & $(0.227)$ \\
\hline Web portals & 6312 & & & 2.633 & $(2.256)$ \\
\hline News agency activities & 6391 & & & 0.928 & $(0.696)$ \\
\hline Other information service activities n.e.c & 6399 & & & $-1.86^{*}$ & $(0.776)$ \\
\hline Legal and accounting activities & 69 & $-0.65 * *$ & $(0.121)$ & & \\
\hline Legal activities & 6910 & & & $-0.97 * *$ & $(0.367)$ \\
\hline Accounting, bookkeeping and auditing activities; tax consultancy & 6920 & & & $-0.68 * *$ & $(0.134)$ \\
\hline Activities of head offices; management consultancy activities & 70 & -0.022 & $(0.030)$ & & \\
\hline Activities of head offices & 7010 & & & -0.002 & $(0.025)$ \\
\hline Public relations and communication activities & 7021 & & & -0.246 & $(0.212)$ \\
\hline Business and other management consultancy activities & 7022 & & & $-0.32 *$ & $(0.131)$ \\
\hline $\begin{array}{l}\text { Architectural and engineering activities; technical testing/ } \\
\text { analysis }\end{array}$ & 71 & $-0.21 * *$ & $(0.078)$ & & \\
\hline Architectural activities & 7111 & & & -0.133 & $(0.241)$ \\
\hline Engineering activities and related technical consultancy & 7112 & & & $-0.22+$ & $(0.120)$ \\
\hline Technical testing and analysis & 7120 & & & $-0.99 * *$ & $(0.274)$ \\
\hline Scientific research and development & 72 & -0.135 & $(0.220)$ & & \\
\hline Research and development on biotechnology & 7211 & & & $0.801^{*}$ & $(0.381)$ \\
\hline Research and development on natural sciences and engineering & 7219 & & & -0.183 & $(0.265)$ \\
\hline Research and development on social sciences and humanities & 7220 & & & -2.094 & $(1.387)$ \\
\hline Advertising and market research & 73 & $0.303+$ & $(0.162)$ & & \\
\hline Advertising agencies & 7311 & & & 0.376 & $(0.250)$ \\
\hline Media representation & 7312 & & & 1.161 & $(1.226)$ \\
\hline Market research and public opinion polling & 7320 & & & 0.048 & $(0.136)$ \\
\hline Other professional, scientific and technical activities & 74 & $-0.50 * *$ & $(0.119)$ & & \\
\hline Specialised design activities & 7410 & & & 0.098 & $(0.781)$ \\
\hline Photographic activities & 7420 & & & 0.934 & $(0.914)$ \\
\hline Translation and interpretation activities & 7430 & & & $8.61 * *$ & $(2.328)$ \\
\hline Other professional, scientific and technical activities n.e.c & 7490 & & & $-0.49 * *$ & $(0.113)$ \\
\hline Constant & & $0.16^{* *}$ & $(0.005)$ & $0.16^{* *}$ & $(0.005)$ \\
\hline Observations & & 2,291 & & 2,291 & \\
\hline $\mathrm{R}$-squared & & 0.537 & & 0.584 & \\
\hline KIBS industry digits & & 2 & & 4 & \\
\hline
\end{tabular}

Clustered standard errors in parentheses $(* * p<0.01, * p<0.05,+p<0.1)$. Estimations of model (2) with the dependant variable: Density ${ }_{t+5}$. The model is estimated twice, once with 2-digit KIBS employment share and once with 4-digit KIBS employment share 
Table 10 Effects on new industrial specialisations in regions with an urban area

\begin{tabular}{|c|c|c|c|c|}
\hline & (1) Density t $_{t+5}$ & (2) Density t $_{t+5}$ & (3) Density t $_{t+5}$ & (4) Density t 5 \\
\hline City & $\begin{array}{l}-0.006 \\
(0.012)\end{array}$ & $\begin{array}{l}0.010 \\
(0.010)\end{array}$ & $\begin{array}{l}-0.009 \\
(0.013)\end{array}$ & $\begin{array}{l}0.016 \\
(0.012)\end{array}$ \\
\hline KIBS & $\begin{array}{l}-0.220^{* *} \\
(0.035)\end{array}$ & & & \\
\hline KIBS $*$ City & $\begin{array}{l}0.145 * * \\
(0.053)\end{array}$ & & & \\
\hline $\mathrm{R} \& \mathrm{D}$ & & $\begin{array}{l}-0.020 \\
(0.255)\end{array}$ & & \\
\hline R\&D * City & & $\begin{array}{l}-0.048 \\
(0.419)\end{array}$ & & \\
\hline T-KIBS & & & $\begin{array}{l}-0.069 \\
(0.046)\end{array}$ & \\
\hline P-KIBS & & & $\begin{array}{l}-0.249 * * \\
(0.040)\end{array}$ & \\
\hline T-KIBS * City & & & $\begin{array}{l}-0.026 \\
(0.114)\end{array}$ & \\
\hline P-KIBS * City & & & $\begin{array}{l}0.217 * * \\
(0.059)\end{array}$ & \\
\hline R\&D-BUS & & & & $\begin{array}{l}0.726+ \\
(0.389)\end{array}$ \\
\hline R\&D-PUB & & & & $\begin{array}{l}-1.925+ \\
(1.027)\end{array}$ \\
\hline R\&D-BUS * City & & & & $\begin{array}{l}-0.116 \\
(0.488)\end{array}$ \\
\hline R\&D-PUB * City & & & & $\begin{array}{l}-0.965 \\
(1.419)\end{array}$ \\
\hline Constant & $\begin{array}{l}0.158 * * \\
(0.006)\end{array}$ & $\begin{array}{l}0.129 * * \\
(0.005)\end{array}$ & $\begin{array}{l}0.158 * * \\
(0.006)\end{array}$ & $\begin{array}{l}0.135 * * \\
(0.006)\end{array}$ \\
\hline Observations & 2,291 & 2,168 & 2,291 & 1,943 \\
\hline R-squared & 0.524 & 0.457 & 0.520 & 0.484 \\
\hline Year FE & Yes & Yes & Yes & Yes \\
\hline Region FE & No & No & No & No \\
\hline Industry FE & Yes & Yes & Yes & Yes \\
\hline
\end{tabular}

Clustered standard errors in parentheses $(* * p<0.01, * p<0.05,+p<0.1)$. Estimations of model (2) with dependant variable: Density $\mathrm{t}_{\mathrm{t}+5}$. For these estimations we have collected an additional dummy variable, which is 1 if a NUTS-2 regions contains a city with more than 750.000 inhabitants. We find that the effects of KIBS are especially important in non-ruban regions and very small in urban regions

\section{Appendix 5: Robustness test without using bootstrapping to determine cut-off points}

See Table 11 


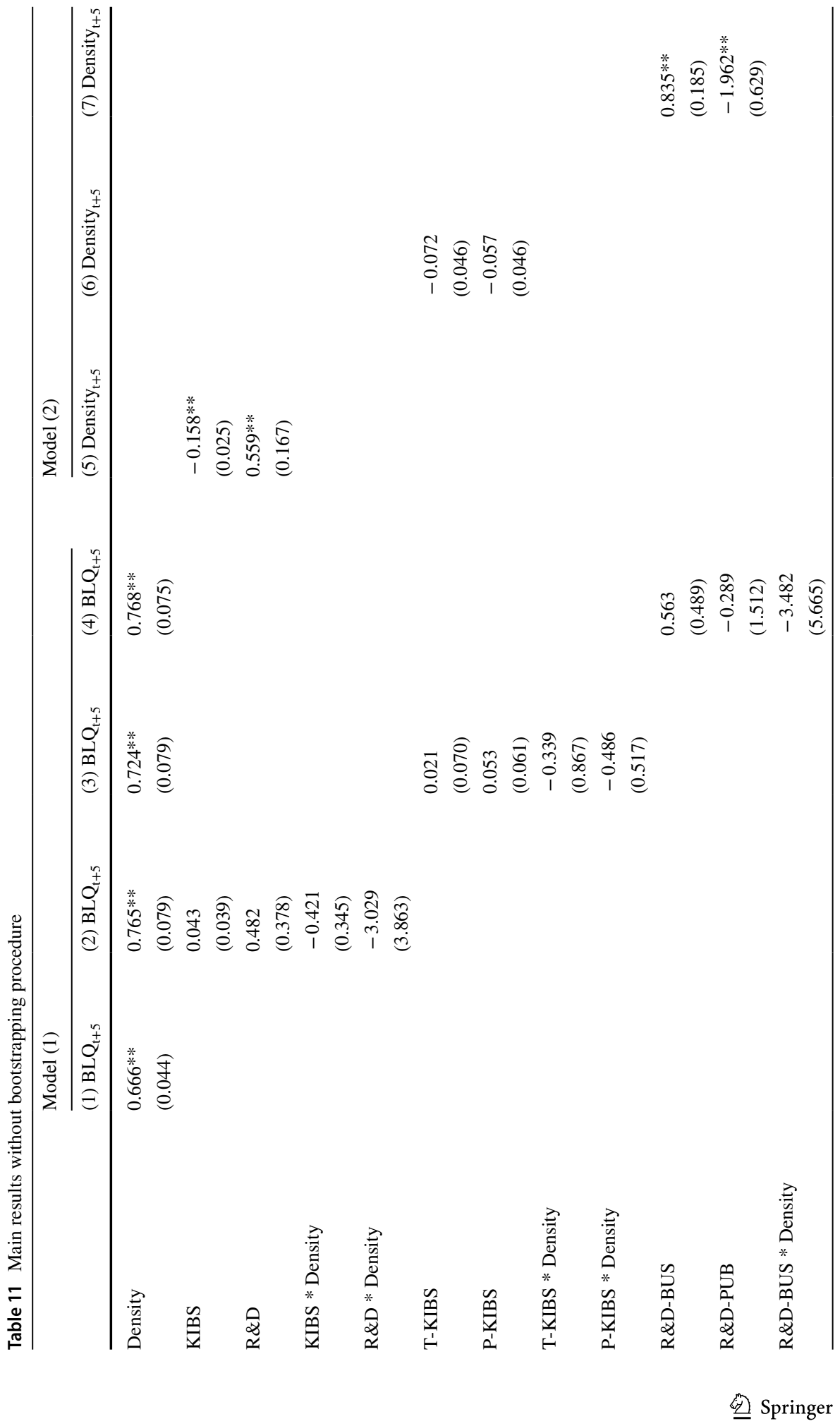




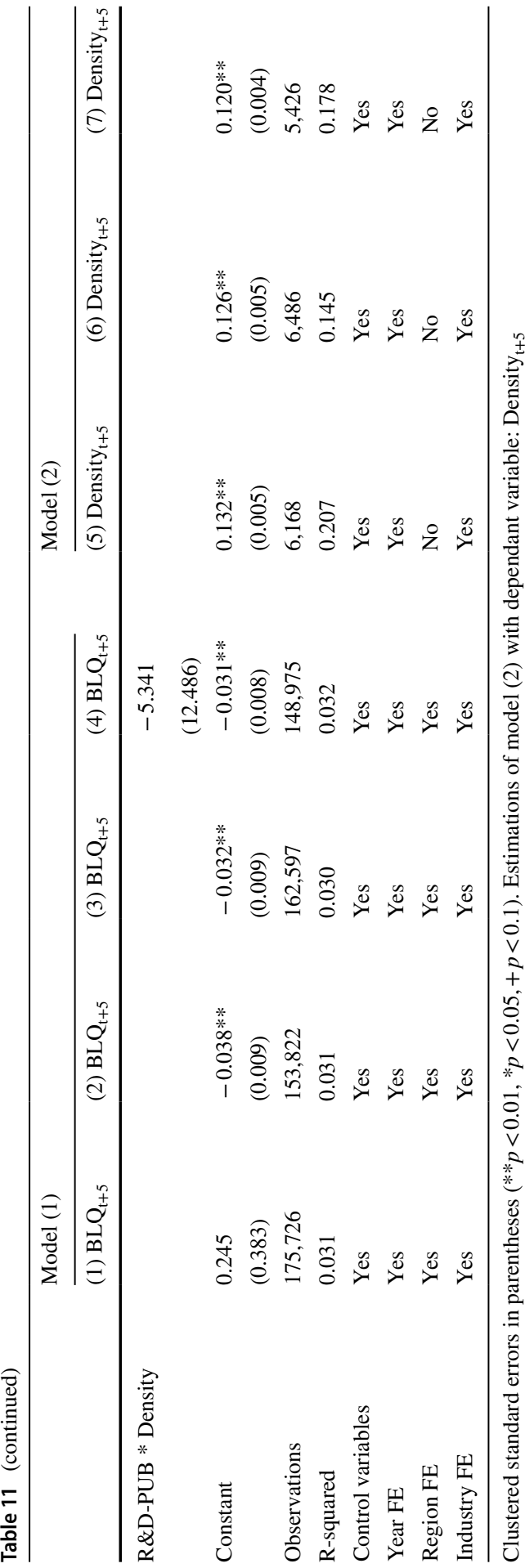


Acknowledgements This work has been supported by the Directorate-General for Research and Innovation, the European Commission, under the H2020 FIRES-project (http://www.projectfires.eu/). We thank the participants of the RSA conference in Dublin (2017), the ERSA conference in Groningen (2017), and the workshop on radical innovation in Bremen (2018) for their helpful comments. We would also like to thank the editor and the referees for their helpful comments during the reviewing process.

Open Access This article is licensed under a Creative Commons Attribution 4.0 International License, which permits use, sharing, adaptation, distribution and reproduction in any medium or format, as long as you give appropriate credit to the original author(s) and the source, provide a link to the Creative Commons licence, and indicate if changes were made. The images or other third party material in this article are included in the article's Creative Commons licence, unless indicated otherwise in a credit line to the material. If material is not included in the article's Creative Commons licence and your intended use is not permitted by statutory regulation or exceeds the permitted use, you will need to obtain permission directly from the copyright holder. To view a copy of this licence, visit http://creativecommons.org/licen ses/by/4.0/.

\section{References}

Acs ZJ, Audretsch DB, Feldman MP (1994) R \& D spillovers and recipient firm size. Rev Econ Stat 76(2):336. https://doi.org/10.2307/2109888

Aghion P, Dewatripont M, Stein JC (2008) Academic freedom, private-sector focus, and the process of innovation. Rand J Econ 39(3):617-635. https://doi.org/10.1111/j.1756-2171.2008.00031.x

Ahuja G, Katila R (2004) Where do resources come from? The role of idiosyncratic situations. Strateg Manag J 25(89):887-907. https://doi.org/10.1002/smj.401

Asheim BT, Isaksen A (2002) Regional innovation systems: the integration of local 'sticky' and global 'ubiquitous' knowledge. J Technol Transf 27(1):77-86. https://doi.org/10.1023/A:1013100704794

Aslesen HW, Isaksen A (2007) Knowledge intensive business services and urban industrial development. Serv Ind J 27(3):321-338. https://doi.org/10.1080/02642060701207239

Audretsch DB, Feldman MP (1996) R\&D spillovers and the geography of innovation and production. Am Econ Rev 86(3):630-640

Bathelt H, Malmberg A, Maskell P (2004) Clusters and knowledge: local buzz, global pipelines and the process of knowledge creation. Prog Hum Geogr 28(1):31-56. https://doi.org/10.1191/0309132504 ph469oa

Binz C, Truffer B, Coenen L (2016) Path creation as a process of resource alignment and anchoring: industry formation for on-site water recycling in Beijing. Econ Geogr 92(2):172-200. https://doi. org/10.1080/00130095.2015.1103177

Boschma R (2015) Towards an evolutionary perspective on regional resilience. Reg Stud 49(5):733-751. https://doi.org/10.1080/00343404.2014.959481

Boschma R (2017) Relatedness as driver of regional diversification: a research agenda. Reg Stud 51(3):351-364. https://doi.org/10.1080/00343404.2016.1254767

Boschma R, Capone G (2015) Institutions and diversification: related versus unrelated diversification in a varieties of capitalism framework. Res Policy 44(10):1902-1914. https://doi.org/10.1016/j.respol. 2015.06.013

Boschma R, Frenken K (2011) The emerging empirics of evolutionary economic geography. J Econ Geograph 11(2):295-307. https://doi.org/10.1093/jeg/lbq053

Boschma R, Minondo A, Navarro M (2013) The emergence of new industries at the regional level in Spain: a proximity approach based on product relatedness. Econ Geogr 89(1):29-51. https://doi.org/ 10.1111/j.1944-8287.2012.01170.x

Bottazzi L, Peri G (2003) Innovation and spillovers in regions: evidence from European patent data. Eur Econ Rev 47(4):687-710

Brenner T, Capasso M, Duschl M, Frenken K, Treibich T (2017) Causal relations between knowledgeintensive business services and regional employment growth. Reg Stud 52(2):172-183. https://doi. org/10.1080/00343404.2016.1265104 
Brusoni S, Prencipe A, Pavitt K (2001) Knowledge specialization, organizational coupling, and the boundaries of the firm: why do firms know more than they make? Adm Sci Q 46(4):597. https://doi. org/10.2307/3094825

Coniglio ND, Lagravinese R, Vurchio D, Armenise M (2018) The pattern of structural change: testing the product space framework. Ind Corp Chang 27(4):763-785. https://doi.org/10.1093/icc/dty009

Content J, Frenken K (2016) Related variety and economic development: a literature review. Eur Plan Stud 24(12):2097-2112. https://doi.org/10.1080/09654313.2016.1246517

Content J, Frenken K, Jordaan JA (2019) Does related variety foster regional entrepreneurship? Evidence from European Regions. Reg Stud 53(11):1531-1543. https://doi.org/10.1080/00343404.2019. 1595565

Cortinovis N, Xiao J, Boschma R, Van Oort F (2017) Quality of government and social capital as drivers of regional diversification in Europe. J Econ Geograph 17(6):1179-1208. https://doi.org/10.1093/ jeg/lbx001

Czarnitzki D, Spielkamp A (2003) Business services in Germany: bridges for innovation. Serv Ind J 23(2):1-30. https://doi.org/10.1080/02642060412331300862

Den Hertog P (2000) Knowledge-intensive business services as co-producers of innovation. Int J Innov Manag 4(04):491-528. https://doi.org/10.1142/S136391960000024X

Den Hertog P (2002) Co-producers of innovation: on the role of knowledge-intensive business services in innovation. In: Gadrey J, Gallouj F (eds) Productivity, innovation and knowledge in services. New economic and socio-economic approaches. Edward Elgar

Essletzbichler J (2015) Relatedness, industrial branching and technological cohesion in US metropolitan areas. Reg Stud 49(5):752-766. https://doi.org/10.1080/00343404.2013.806793

Feldman MP, Florida R (1994) The geographic sources of innovation: technological infrastructure and product innovation in the United States. Ann Assoc Am Geogr 84(2):210-229. https://doi.org/ 10.1111/j.1467-8306.1994.tb01735.x

Fernandes CI, Ferreira JJM (2013) Knowledge spillovers: cooperation between universities and KIBS: cooperation between universities and KIBS. R\&D Manag 43(5):461-472. https://doi.org/10. $1111 /$ radm. 12024

Foray D, David PA, Hall B (2009) Smart specialisation-the concept. Knowl Econ Policy Brief 9(85): 100

Forti E, Franzoni C, Sobrero M (2013) Bridges or isolates? Investigating the social networks of academic inventors. Res Policy 42(8):1378-1388. https://doi.org/10.1016/j.respol.2013.05.003

Frenken K (2017) A complexity-theoretic perspective on innovation policy. Complex Innov Policy 3(1):35-47

Frenken K, Boschma RA (2007) A theoretical framework for evolutionary economic geography: industrial dynamics and urban growth as a branching process. J Econ Geograph 7(5):635-649. https://doi.org/10.1093/jeg/lbm018

Greene WH (2012) Econometric analysis, 7th edn. Prentice Hall

Griliches Z (1991) The search for R\&D spillovers. National Bureau of Economic Research Working Paper Series, (w3768)

Grillitsch M, Trippl M (2014) Combining knowledge from different sources, channels and geographical scales. Eur Plan Stud 22(11):2305-2325. https://doi.org/10.1080/09654313.2013.835793

Guimarães P, Figueiredo O, Woodward D (2009) Dartboard tests for the location quotient. Reg Sci Urban Econ 39(3):360-364. https://doi.org/10.1016/j.regsciurbeco.2008.12.003

Hausmann R, Klinger B (2007) The structure of the product space and the evolution of comparative advantage. CID Working Paper Series

Hidalgo CA, Hausmann R (2009) The building blocks of economic complexity. Proc Natl Acad Sci 106(26):10570-10575. https://doi.org/10.1073/pnas.0900943106

Hidalgo CA, Klinger B, Barabási A-L, Hausmann R (2007) The Product Space Conditions the Development of Nations. Science 317(5837):482-487. https://doi.org/10.1126/science.1144581

Hipp C (1999) Knowledge-intensive business services in the new mode of knowledge production. AI Soc 13(1-2):88-106

Isaksen A (2015) Industrial development in thin regions: Trapped in path extension? J Econ Geograph 15(3):585-600. https://doi.org/10.1093/jeg/lbu026

Jaffe AB, Trajtenberg M, Henderson R (1993) Geographic localization of knowledge spillovers as evidenced by patent citations. Q J Econ 108(3):577-598 
Janssen MJ (2019) What bangs for your buck? Assessing the design and impact of Dutch transformative policy. Technol Forecast Soc Chang 138:78-94. https://doi.org/10.1016/j.techfore.2018.08. 011

Janssen MJ, Castaldi C (2018) Services, innovation, capabilities, and policy: toward a synthesis and beyond. Sci Public Policy 45(6):863-874. https://doi.org/10.1093/scipol/scy017

Janssen MJ, Castaldi C, Alexiev AS (2018) In the vanguard of openness: which dynamic capabilities are essential for innovative KIBS firms to develop? Ind Innov 25(4):432-457. https://doi.org/10. 1080/13662716.2017.1414758

Janssen MJ, Frenken K (2019) Cross-specialisation policy: rationales and options for linking unrelated industries. Camb J Reg Econ Soc 12(2):195-212. https://doi.org/10.1093/cjres/rsz001

Lafuente E, Vaillant Y, Vendrell-Herrero F (2017) Territorial servitization: exploring the virtuous circle connecting knowledge-intensive services and new manufacturing businesses. Int J Prod Econ 192:19-28. https://doi.org/10.1016/j.ijpe.2016.12.006

Landry R, Amara N, Doloreux D (2012) Knowledge-exchange strategies between KIBS firms and their clients. Serv Ind J 32(2):291-320. https://doi.org/10.1080/02642069.2010.529131

Lau AKW, Lo W (2015) Regional innovation system, absorptive capacity and innovation performance: an empirical study. Technol Forecast Soc Chang 92:99-114. https://doi.org/10.1016/j. techfore.2014.11.005

Lissoni F (2010) Academic inventors as brokers. Res Policy 39(7):843-857. https://doi.org/10.1016/j. respol.2010.04.005

Martin R, Sunley P (2006) Path dependence and regional economic evolution. J Econ Geograph 6(4):395-437. https://doi.org/10.1093/jeg/lb1012

Maskell P, Bathelt H, Malmberg A (2006) Building global knowledge pipelines: the role of temporary clusters. Eur Plan Stud 14(8):997-1013. https://doi.org/10.1080/09654310600852332

Maskell P, Malmberg A (2007) Myopia, knowledge development and cluster evolution. J Econ Geograph 7(5):603-618. https://doi.org/10.1093/jeg/lbm020

Miles I, Kastrinos N, Bilderbeek R, den Hertog P, Flanagan K, Huntink W, Bouman M (1995) Knowledge-intensive business services: users, carriers and sources of innovation

Muller E, Zenker A (2001) Business services as actors of knowledge transformation: the role of KIBS in regional and national innovation systems. Res Policy 30(9):1501-1516. https://doi.org/10. 1016/S0048-7333(01)00164-0

Neffke F, Hartog M, Boschma R, Henning M (2018) Agents of structural change: the role of firms and entrepreneurs in regional diversification. Econ Geogr 94(1):23-48. https://doi.org/10.1080/ 00130095.2017 .1391691

Neffke F, Henning M, Boschma R (2011) How do regions diversify over time? Industry relatedness and the development of new growth paths in regions. Econ Geogr 87(3):237-265. https://doi.org/ 10.1111/j.1944-8287.2011.01121.x

Petralia S, Balland P-A, Morrison A (2017) Climbing the ladder of technological development. Res Policy 46(5):956-969. https://doi.org/10.1016/j.respol.2017.03.012

Rodriguez M (2013) Knowledge-intensive business services and R\&D diffusion: a comparative assessment of some EU27 Countries. Eng Econ. https://doi.org/10.5755/j01.ee.24.4.2081

Rodriguez M, Doloreux D, Shearmur R (2017) Variety in external knowledge sourcing and innovation novelty: evidence from the KIBS sector in Spain. Technovation 68:35-43. https://doi.org/10. 1016/j.technovation.2017.06.003

Schnabl E, Zenker A (2013) Statistical classification of knowledge-intensive business services (KIBS) with NACE Rev. 2. Fraunhofer ISI, Karlsruhe

Simmie J (2003) Innovation and urban regions as national and international nodes for the transfer and sharing of knowledge. Reg Stud 37(6-7):607-620. https://doi.org/10.1080/003434003200010 8714

Simmie J, Martin R (2010) The economic resilience of regions: towards an evolutionary approach. Camb J Reg Econ Soc 3(1):27-43. https://doi.org/10.1093/cjres/rsp029

Simmie J, Strambach S (2006) The contribution of KIBS to innovation in cities: an evolutionary and institutional perspective. J Knowl Manag 10(5):26-40. https://doi.org/10.1108/1367327061 0691152

Tanner AN (2014) Regional branching reconsidered: emergence of the fuel cell industry in European regions: regional branching reconsidered. Econ Geogr 90(4):403-427. https://doi.org/10.1111/ ecge. 12055 
Toivonen M (2004) Foresight in services: possibilities and special challenges. Serv Ind J 24(1):79-98 Tomlinson M (1999) The learning economy and embodied knowledge flows in Great Britain. J Evol Econ 9(4):431-451

Trippl M, Grillitsch M, Isaksen A (2017) Exogenous sources of regional industrial change: Attraction and absorption of non-local knowledge for new path development. Prog Hum Geogr. https://doi. org/10.1177/0309132517700982

Windrum P, Tomlinson M (1999) Knowledge-intensive services and international competitiveness: a four country comparison. Technol Anal Strat Manag 11(3):391-408

Wood P (2006) Urban development and knowledge-intensive business services: too many unanswered questions?: Urban development and KIBS. Growth Chang 37(3):335-361. https://doi.org/10. $1111 /$ j.1468-2257.2006.00327.x

Wyrwich M (2019) New KIBS on the bloc: The role of local manufacturing for start-up activity in knowledge-intensive business services. Reg Stud 53(3):320-329. https://doi.org/10.1080/00343 404.2018.1478076

Xiao J, Boschma R, Andersson M (2018) Industrial diversification in Europe: the differentiated role of relatedness. Econ Geogr 94(5):514-549. https://doi.org/10.1080/00130095.2018.1444989

Zhu S, He C, Zhou Y (2017) How to jump further and catch up? Path-breaking in an uneven industry space. J Econ Geograph 17(3):521-545. https://doi.org/10.1093/jeg/lbw047

Publisher's Note Springer Nature remains neutral with regard to jurisdictional claims in published maps and institutional affiliations. 